\title{
Prediction of the Starting and Ending of Freezing Periods of Ardabil Province by Using HADCM3 Climatic Model
}

\section{ART I C L E I N F O}

\section{Article Type}

Original Research

\section{Authors}

Sobhani B. ${ }^{1} P h D$

Goldust A.* $M A$

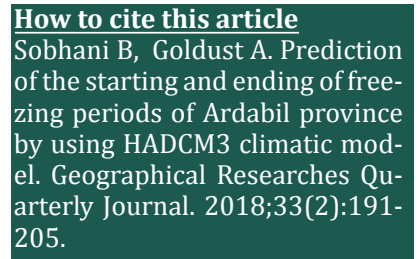

${ }^{1}$ Department of Natural Geography, Faculty of Literature and $\mathrm{Hu}-$ man Sciences, University of Mohaghegh Ardabili, Iran

*Department of Meteorology, Faculty of Literature and Human Sciences, University of Mohaghegh Ardabili, Iran

\section{*Correspondence}

Address: Department of Meteorology, Faculty of Literature and Human Sciences, University of Mohaghegh Ardabili, Iran

Phone: -

Fax: -

Akbar.goldust@gmail.com

\section{Article History}

Received: -

Accepted: -

ePublished: -

\section{A B S T R A C T}

Introduction and Background One of the causes of the widespread damages caused by frost is the fact that its dimensions and nature are unknown. The prediction of frosts is one of the issues that, if implemented, can be a very great help in reducing the adverse effects of this phenomenon.

Aims In this research, daily minimum temperature is predicted for analyzing the start and end of freezing period in Parsabad, Ardabil and Khalkhal stations for next three periods 2011- 2030, 20462065 and $2080-2099$.

Methodology Used data was data related to meteorological models, daily rainfall data, max and min temperature and sunny hours from 1996 to 2016. First, to choose the efficient model of general circulation of atmosphere, the results of nine climatic models were compared, and HADCM3 model was selected as the best model. This model's output was down scaled by LARS-WG downscaling method. This method is very effective in downscaling of applied model's output. After simulation of daily minimum temperature for future periods; with regard to being correct of real data from 2011 to 2016; simulated data was compared with real data.

Conclusion Results showed that simulated data don't have significant difference with station's real data. Therefore, meteorological model of HADCM3 has acceptable capability in this simulation. According to the results obtained from this research, minimum mean temperature of stations in future years will be increasing. Date of freezing starting is delayed eventually in future periods and starting and ending date of them is closed together over the time and freezing period duration is more shortened. Date of freezing starting in Khalkhal station was the first day of October through 7th of October, in Ardabil station between 9th of October through 30th October and in Parsabad station between 10th of November through 8th of December. Date of freezing ending in Khalkhal station was estimated 13th of April through 18th of May, in Ardabil station between 17th of April through 18th May and in Parsabad station between 26th April through 28th of March.

Keywords Prediction; Freezing; HadCM3; Ardabil Province

\section{I T A T I O N L I N KS}

[Ababaei, et al; 2010] Effect of climate change ...; [Abbasi, et al; 2012] Estimation of Iran's climate ... [Ahmadi, et al; 2015] Investigating the effects of ...; [Aliyari, et al; 2008] Short-term prediction of air ...; [Andersen, et al; 2006] Climate-change impacts on hydrology ...; [Ashofte \& Bozorg Hadad; 2015] Assessments of risk-based of crops ...; [Ashraf, et al; 2011] Preliminary estimation of sugar beet ...; [Babaeian \& Kouhi; 2011] Evaluation of agricultural climate ...; [Bahmanesh, et al; 2015] Effect of climate change on ...; [Dai, et al; 1997] Surface observed global land ...; [Darand \& Masoodian; 2015] Waiting time of frost ...; [Ekström, et al; 2005] New estimates of future changes in ...; [Elguindi \& Giorgi; 2006] Simulating multi-decadal variability of ...; [Hejazizadeh, et al; 2012] Evaluating the effect of climate change on ...; [Hejazizadeh \& Naserzadeh; 2005] Calculating and analyzing ...; [Kazemirad \& Mohammadi; 2015] Evaluation of the proper model of ...; [Khaliliaghdam \& Soltani; 2009] Assessment of climate change ...; [Khaliliaqdam, et al; 2013] Evaluation of ability of LARS-WG ...; [Khosravi, et al; 2015] Simulation of climate change in ...; [Livingston, et al; 2016] Differences between wheat ...; [Mahdi zadeh, et al; 2011] Investigating the Effect of Climate ...; [Mahmoudi, et al; 2015] Relationship between tele ...; [Mahmoudi, et al; 2013] Atlas of climatology of ...; [Massoudian \& Darand; 2015] Investigating the trend of the number ...; [Mirmosavi \& Hosseinbabaii; 2011] Study of temporal-spatial ...; [Modaresi, et al; 2011] Investigating the effect of climate ...; [Mozaffari; 2013] Investigation of the process of ...; [Omidvar \& Aslani; 2014] Analyzing and analyzing the temporal and ...; [Osati, et al; 2015] Trend analysis of streamflow in Karkheh Rivers: ...; [Reinsdorf \& Koch; 2013] Modeling crown temperature of winter ...; [Rezaei Banafsheh, et al; 2015] Investigating the effect of climate change ...; [Sarafroozeh, et al; 2012] Evaluation of the effects of future climate ...; [Semenov, et al; 1998] Comparison of the WGEN and ...; [Soltani \& Ghoilipur; 2006] Simulation of the effect of climate ...; [Steele-Dunne, et al; 2008] The impacts of climate change on hydrology ...; [Yao, et al; 2007] Assessing the impacts of climate ... 
Sobhani B. PhD

Goldust A. MA

Akbar.goldust@gmail.com

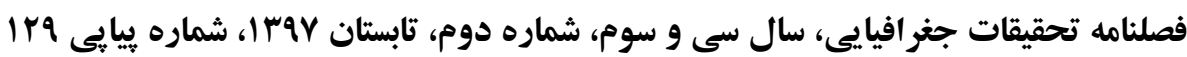

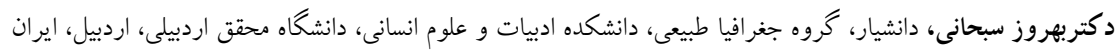

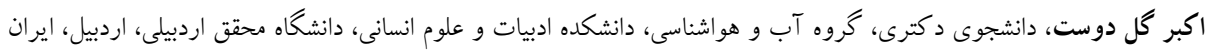

\section{بيشبينى تاريخهاى آغاز و بايان يخبندانهاى استان اردبيل با استفاده از خروجى مدل اقليمى HADCM3}

يذيرش نهايى:TV/T/M

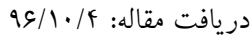

مقدمه: يكى از علل كسترده بودن خسارات ناشى از يخبندان، ناشناخته ماندن ابعاد و ماهيت آن مىباشد. يِيشبينى يخبندانها

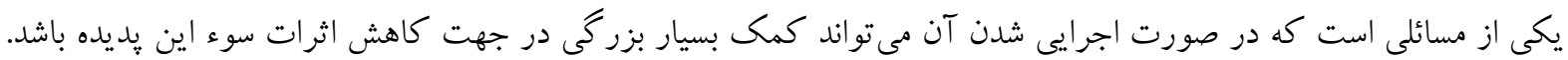

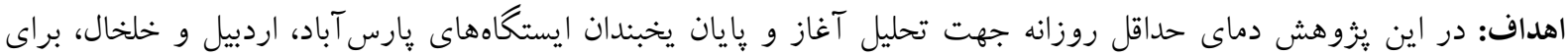

$$
\text { سه دوره آتى ·r.r-r- }
$$

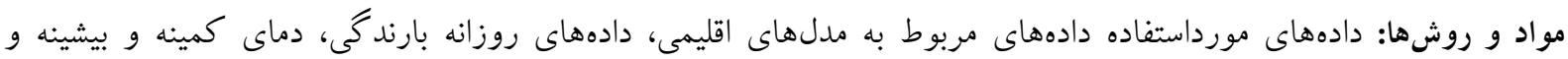

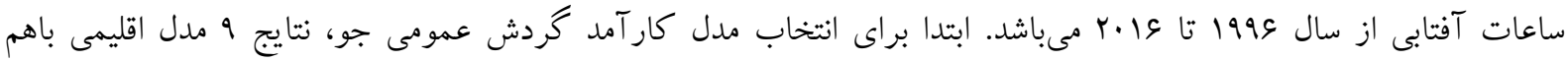

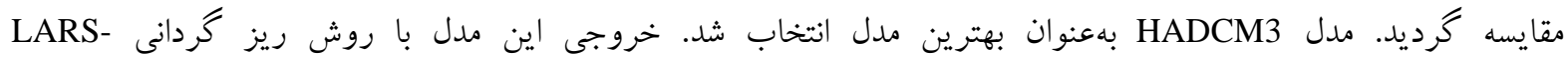

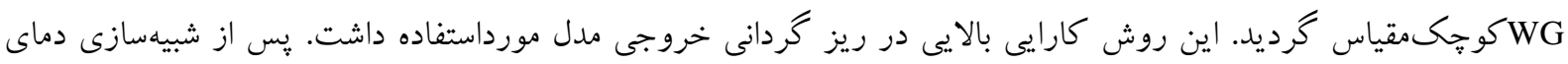

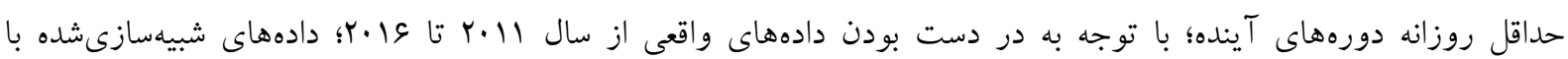

$$
\text { دادههاى واقعى مقايسه گرديد. }
$$

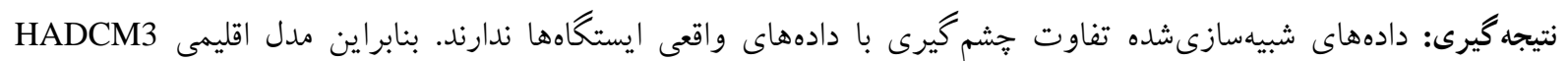

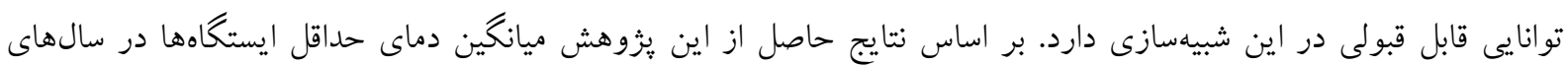

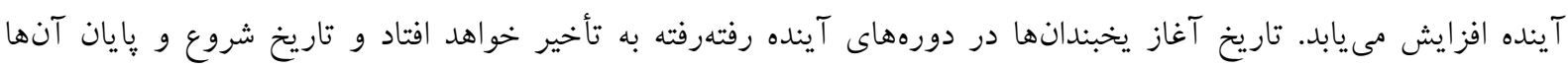

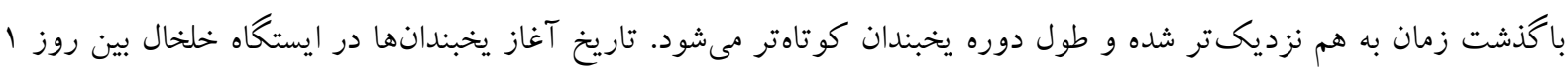

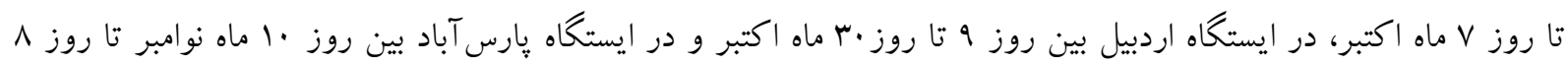

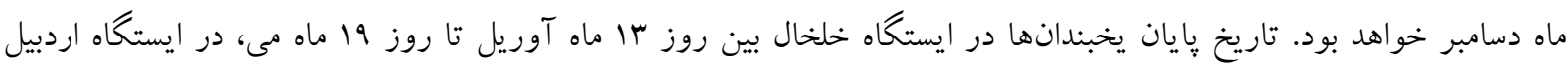

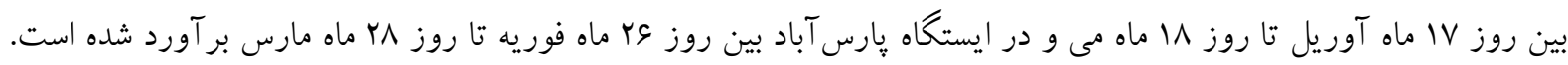

وازگًان كليدى: بيشبينى، يخبندان، HADCM3، استان اردبيل

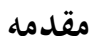

تغيير اقليم يكى از معضلات كنونى جامعه بشرى است و تهديد و بلايى براى سياره زمين به شمار مى آيد. تغييرات

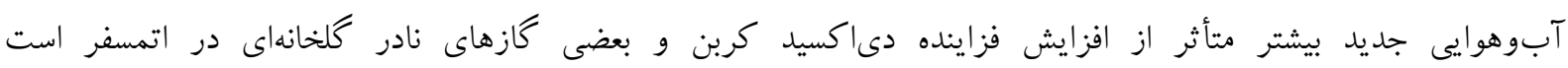


(Khaliliaghdam \& Soltani, 2009)

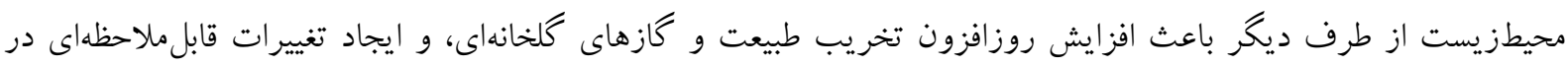

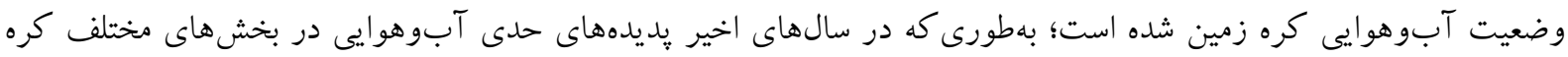

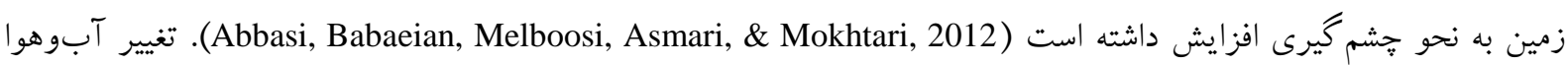

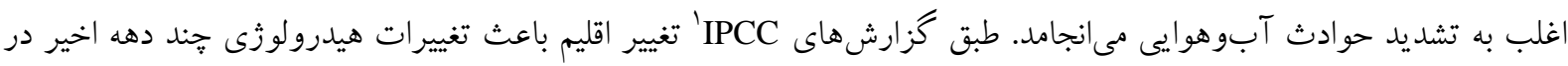

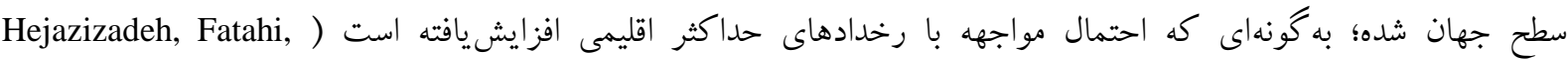
(Masoumeh Bavani, \& Naserzadeh, 2012

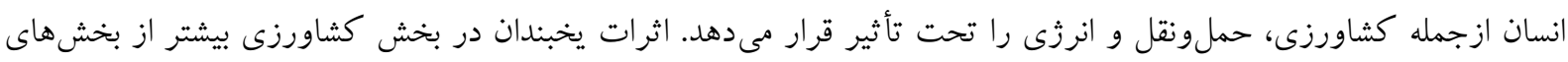

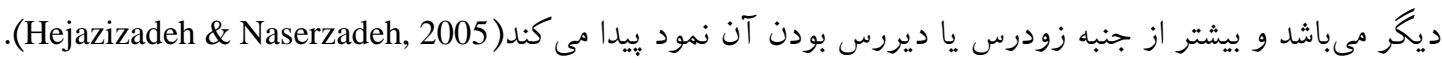

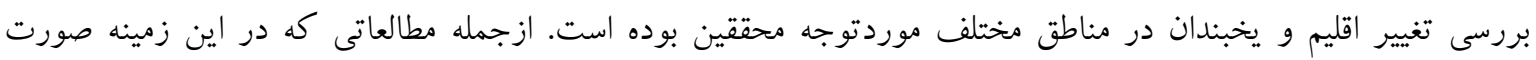

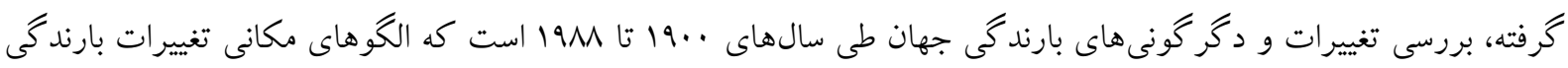

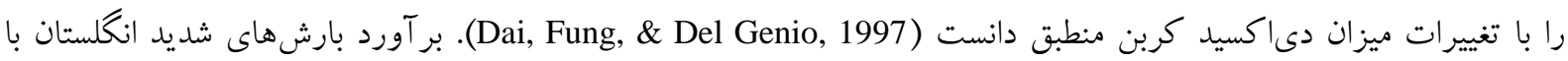
مدل اقليمى HadRM3 نشان از تشديد بارندگى ها در دورههاى آتى دارد (Ekström, Fowler, Kilsby, \& Jones, 2005). نتايج

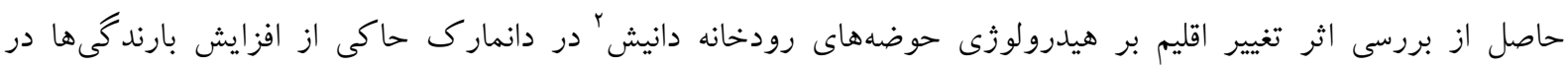

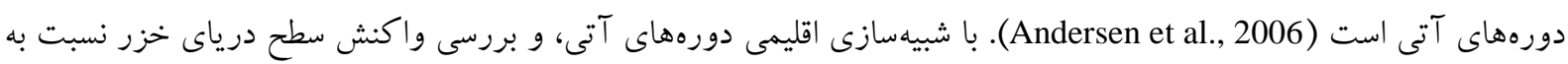

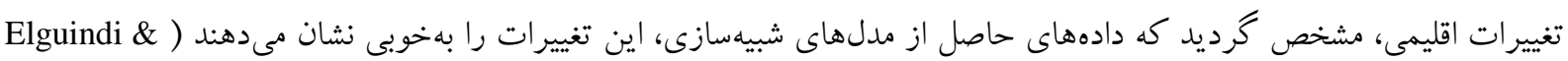

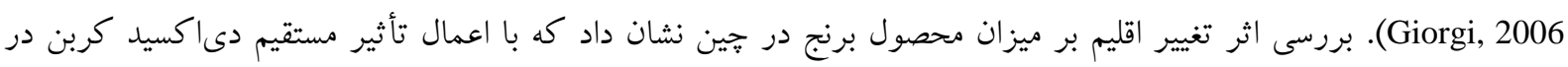

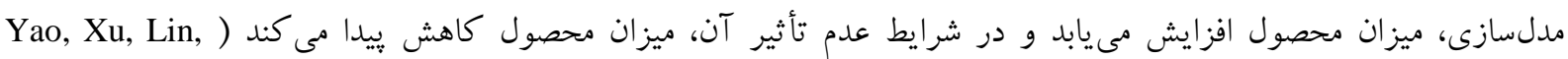

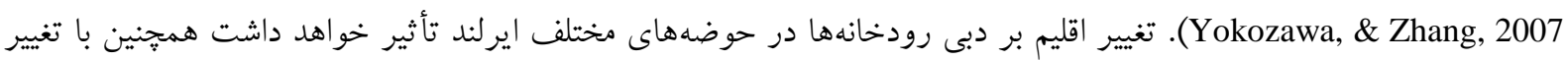

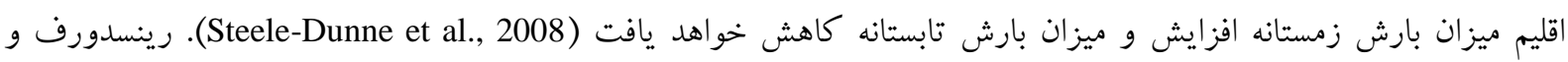

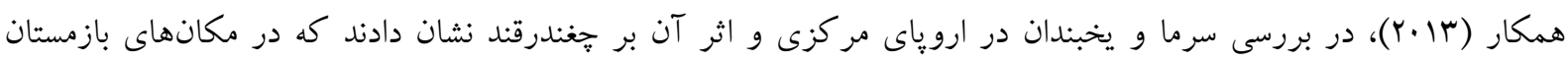

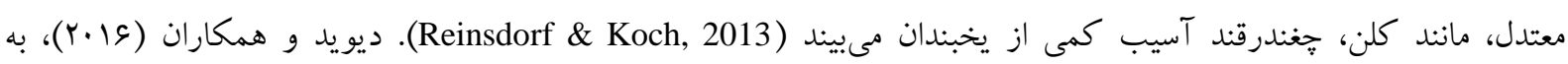

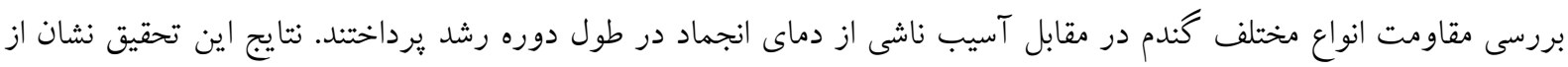

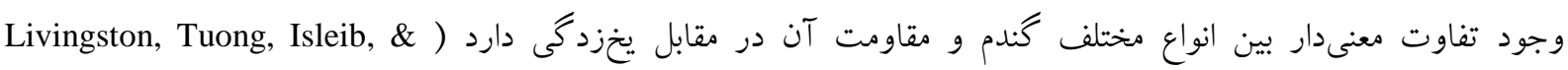

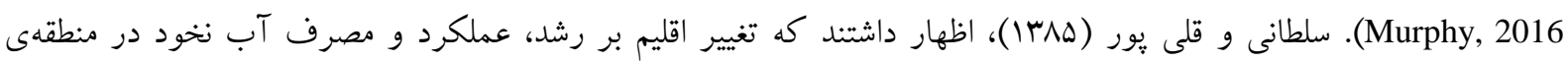

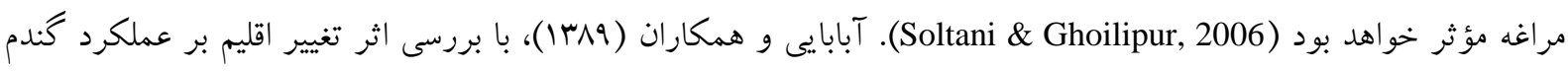

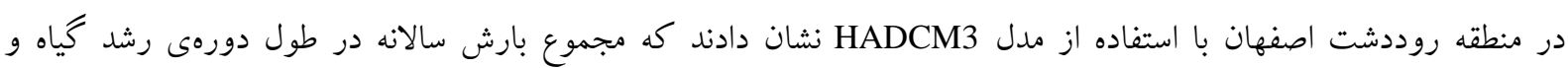

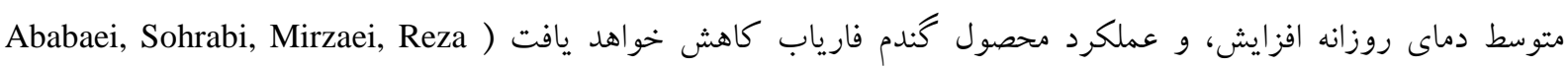
Verdi-Nejad, \& Karimi, 2010

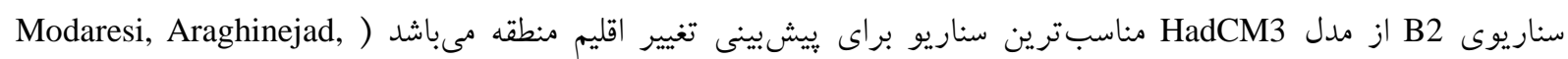
(Ebrahimi, \& Kholghi, 2011

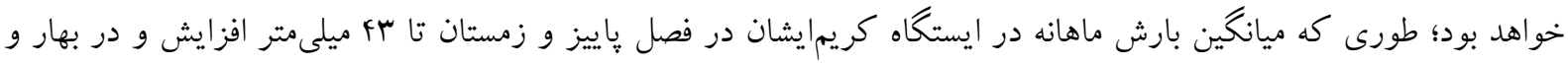




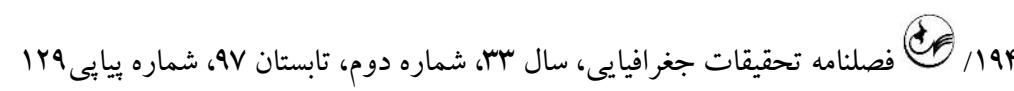
تابستان تا سז ميلىمتر كاهش مىيابد (Mahdi zadeh, Meftah Halghi, Seyyed Ghasemi, \& Mosaedi, 2011). بررسى

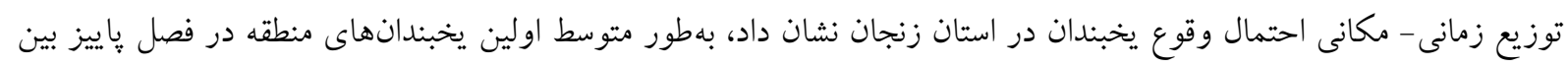

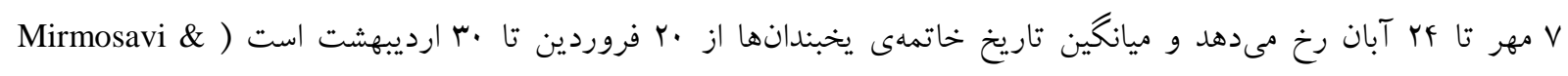

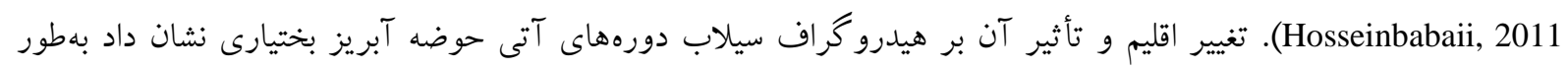

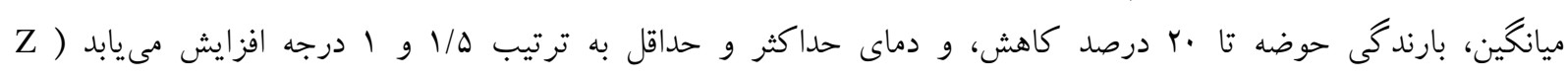

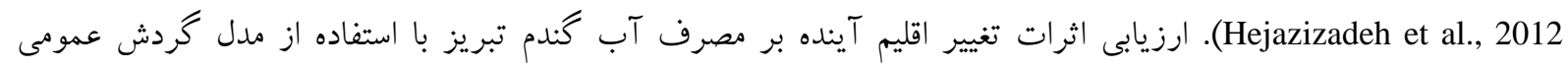

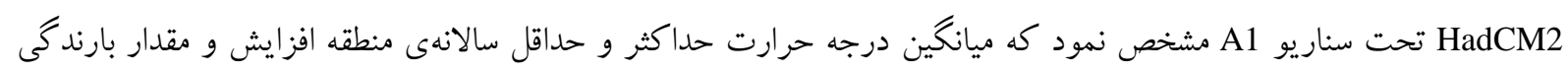

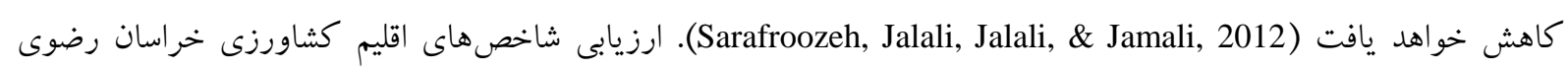

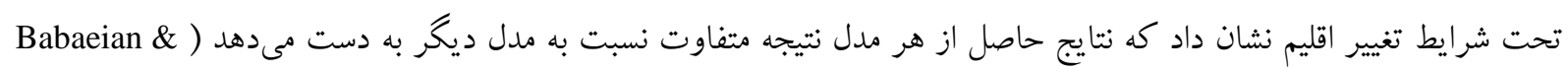

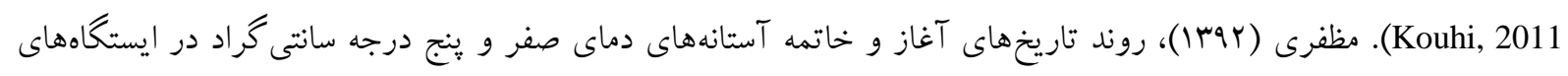

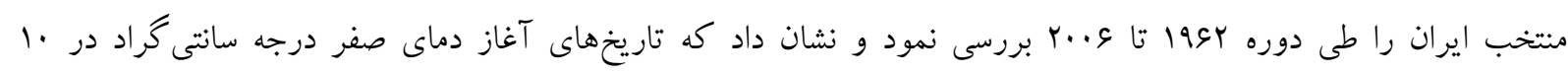

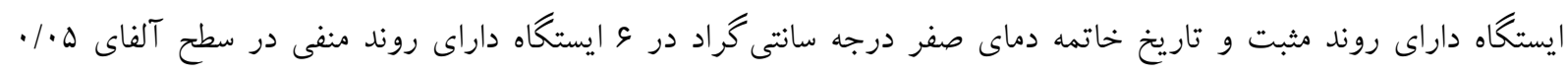

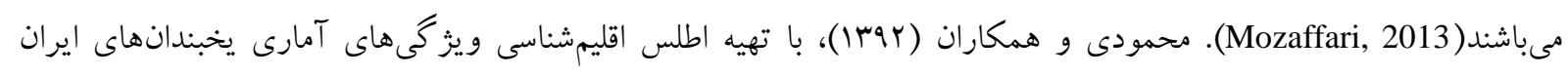

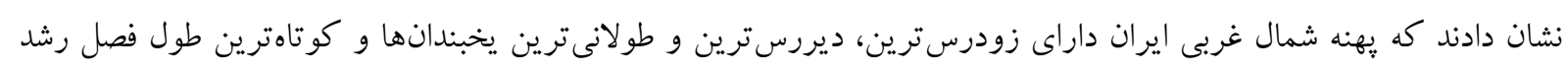

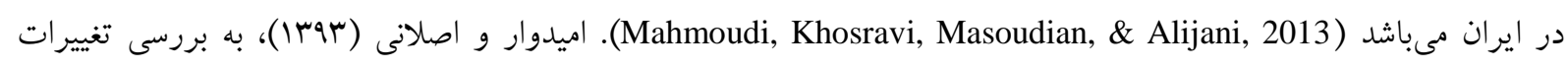

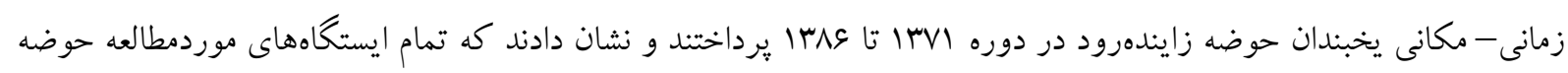

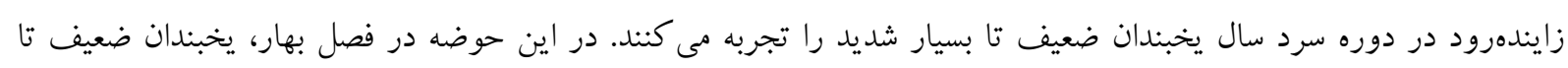

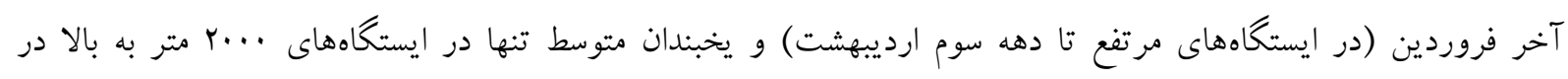

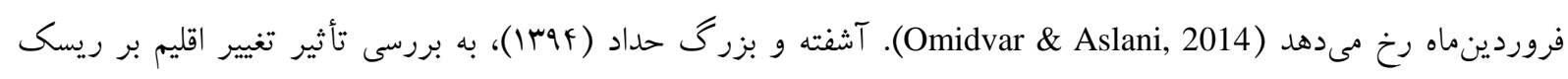

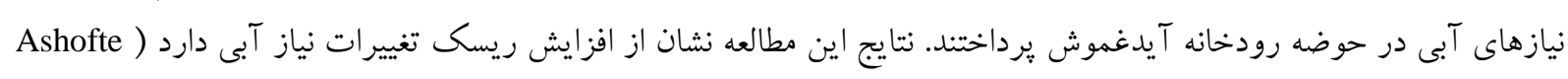

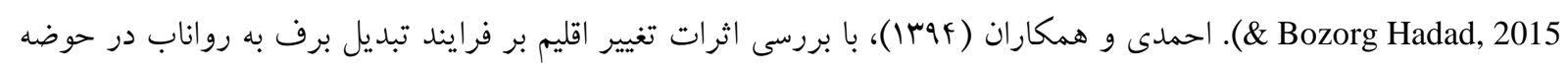

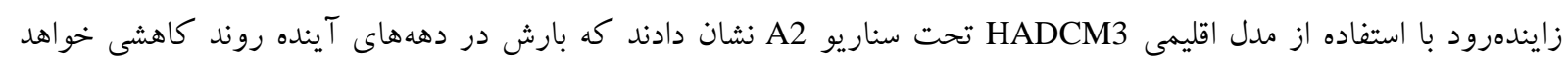

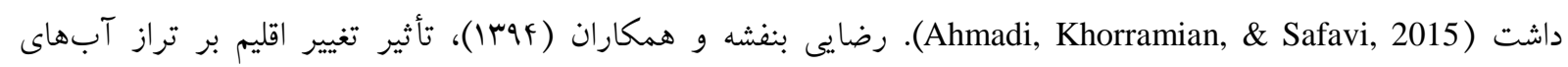

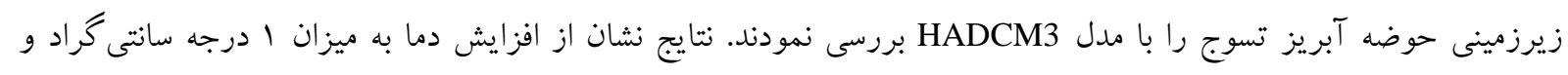

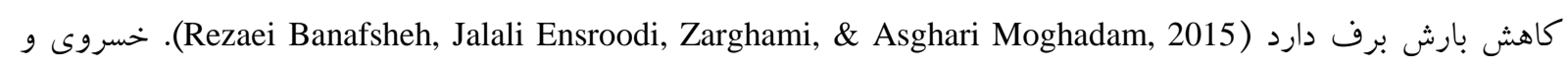

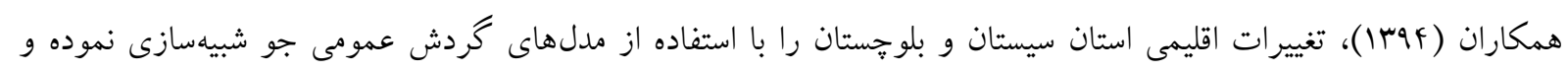

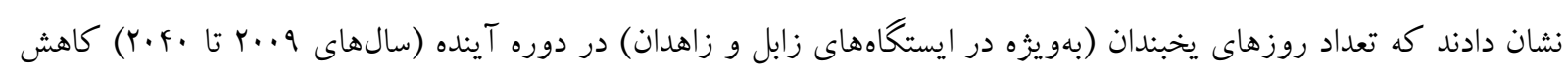

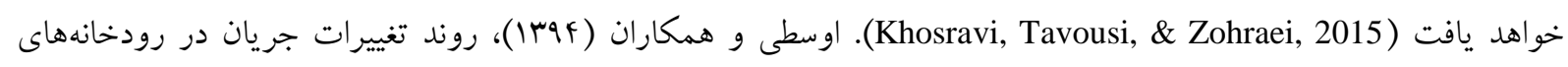

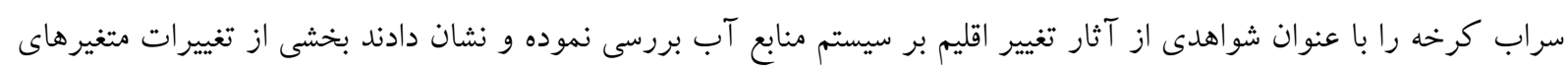

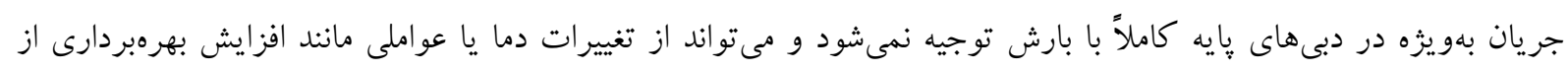

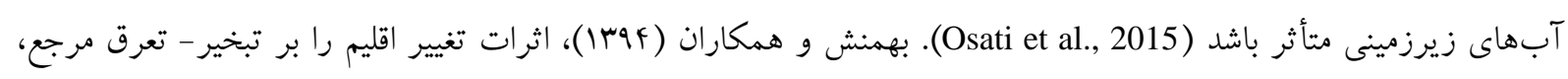

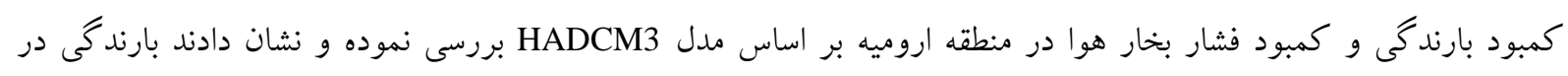

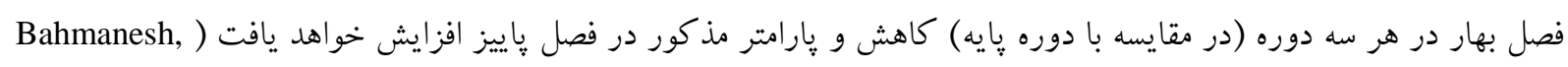


(Azad Talatape, Montaseri, Rezaei, \& Khalili, 2015

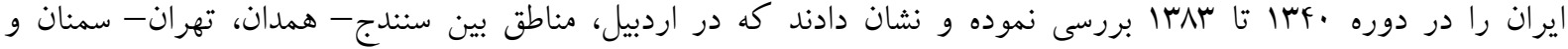
Darand \& Masoodian, ) شهر كرد نسبت به ساير مناطق كشور فاصله زمانى بين رخداد دو يخبندان متوالى بسيار كوتاه است 2015). محمودى و همكاران (FF (IF)، به بررسى رابطه بين الكوهاى ييوند از دور و يخبندانهاى فراكير در ايران يرداختند. نتايج نشان داد فراوانى روزهاى همراه با يخبندانهاى فراگير در فصل زمستان و همجنين در مقياس سالانه، تنها با الكوى اطلس Mahmoudi, Khosravi, Mas'udiyan, \& Alijani, ) شرقى رابطه معنادار نشان مىدهد و اين رابطه يك رابطه معكوس مىباشي

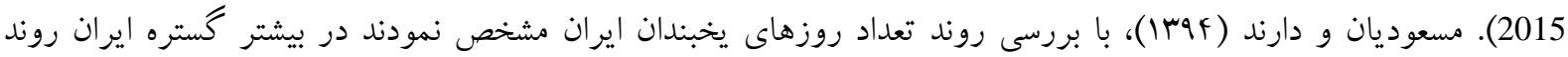
تعداد روزهاى يخبندان رو به كاهش است (Massoudian \& Darand, 2015). كاظمى راد و محمدى (MqF)، در بررسى

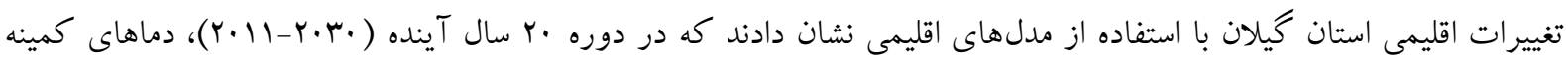

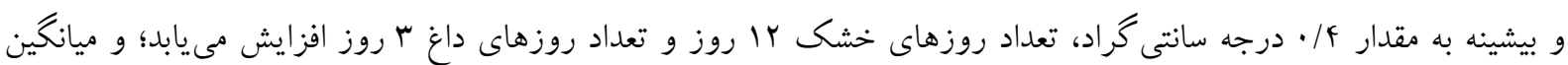

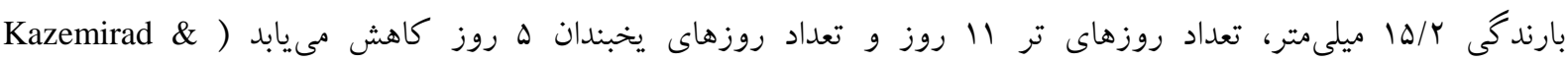

.(Mohammadi, 2015

بررسى ييشينه يُوهش نشان مىدهد كه در اكثر موارد تغيير اقليم بر عناصر و گارامترهاى موردمطالعه تأثير داشته و در دورههاى آينده عناصر و يديدههاى اقليمى نسبت به دوره كذشته دجار تغيير مىشود. يكى از يديدههاى مهم آبوهوايى كه مناطق سردسير كشور را تحت تأثير قرار مىدهد، يخبندانهاى زودرس و ديررس مىباشد. در استان اردبيل در بيشتر سالها اين يديده آسيب زيادى به محصولات كشاورزى وارد مىنمايد. يكى از علل كسترده بودن خسارات ناشى از يخبندانها، ناشناخته ماندن ابعاد و ماهيت آن مىباشد. بحث ييشبينى يخبندانها يكى از مسائلى است كه در صورت اجرايى شدن آن مىتواند كمك بسيار بزركى براى كاهش اثرات سوء اين زيديده باشد. روشهاى مختلفى براى بيشبينى پيديدهاى اقليمى به كار گرفته مىشود؛ اما بدون توجه به اين واقعيت كه اقليم در حال تغيير است، نمىتوان بيشبينى واقعبينانهاى را انجام داد. بنابراين هدف اصلى تحقيق حاضر ييش بينى و تحليل تاريخهاى آغاز و يايان يخبندانهاى زودرس و ديررس استان اردبيل تحت شرايط تغيير اقليم مىباشد. كه ضمن اين هدف اصلى؛ توانايى مدلهاى مختلف اقليمى و روش ريز گردانى در شبيهسازى و بازتوليد دماى حداقل روزانه، و ميزان تغييرات دماى حداقل روزانه در دورههاى آينده نسبت به دوره كذشته بررسى شود.

\section{مواد و روشها}

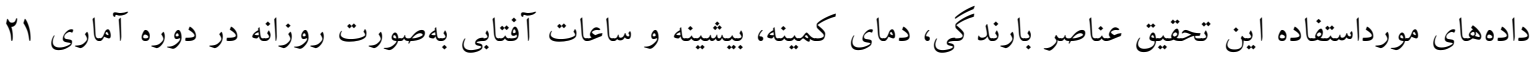

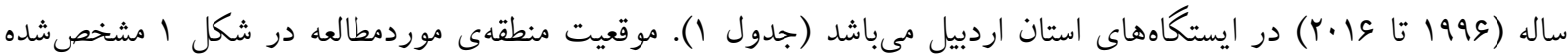
است. يس از تهيه دادها از سازمان هواشناسى كشور، با استفاده از آزمون رانتست همكنى و تصادفى بودن دادهها بررسى و در سطح ه9 درصد تأييد شد.

\section{جدول ا - ايستغاههاى موردمطالعه}

\begin{tabular}{|c|c|c|c|}
\hline ارتفاع از سطح دريا (M) & طول جغرافيايى (E) & عرض جغرافيايى (N) & ايستكاه \\
\hline$r / / q$ & $\Delta \Delta^{\circ} F V^{\prime}$ & $r q^{\circ} r q^{\prime}$ & يارس آباد \\
\hline 每 & $I V^{0} F \Lambda^{\prime}$ & $10^{\circ} \mu \Lambda^{\prime}$ & اردبيل \\
\hline IV9S & $M I^{\circ} F \Lambda^{\prime}$ & $r \Lambda^{\circ} \mu v^{\prime}$ & خلخال \\
\hline
\end{tabular}




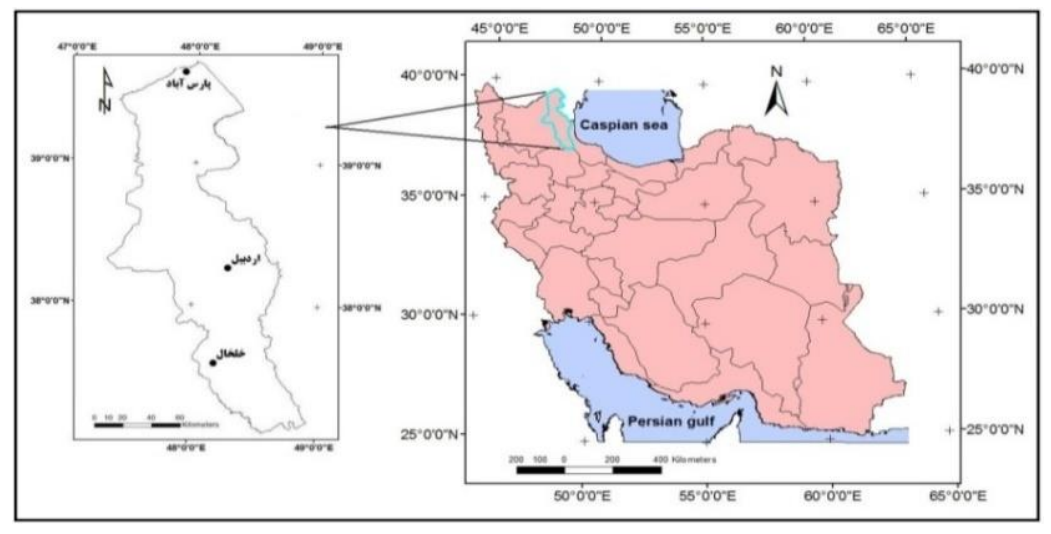

شكل 1- موقعيت منطقه موردمطالعه

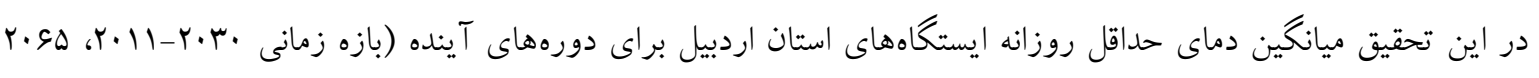

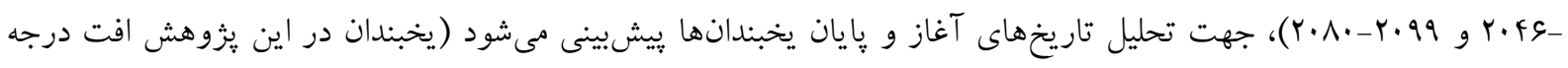

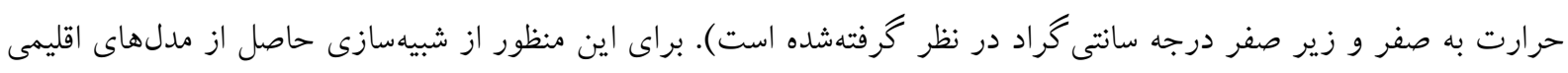

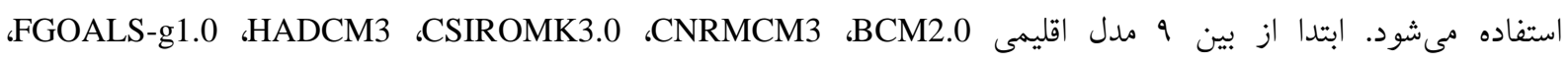
CGCM3T63 بلعنوان مدل مورداستفاده انتخاب مىشود. از اين طريق سعى مىشود عدم قطعيت موجود در مدل انتخابشده كاهش يابد.

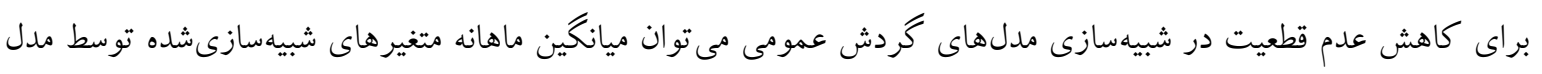

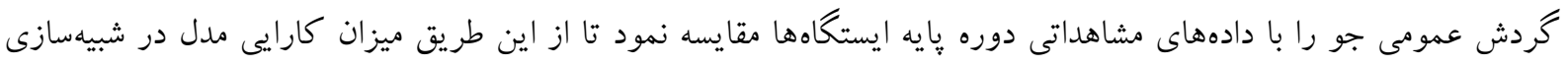

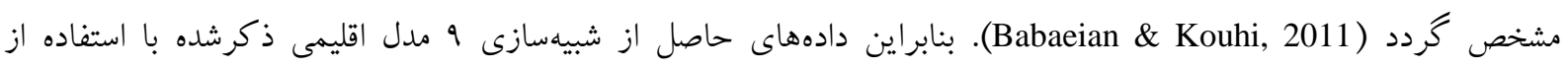

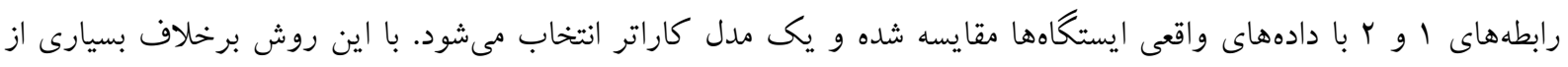

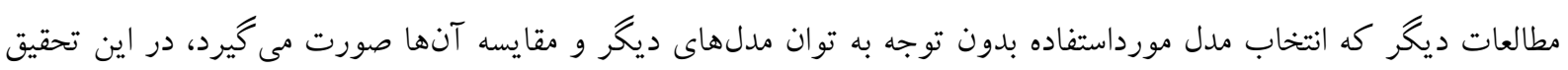

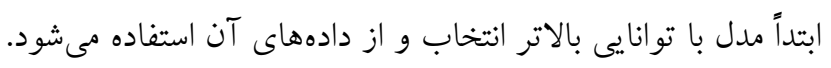

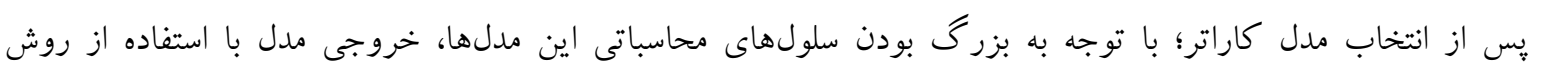

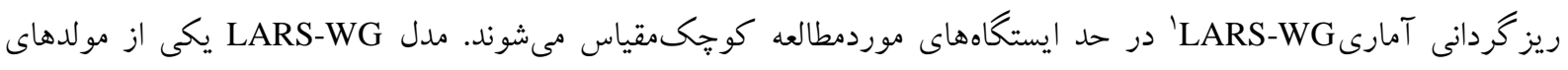

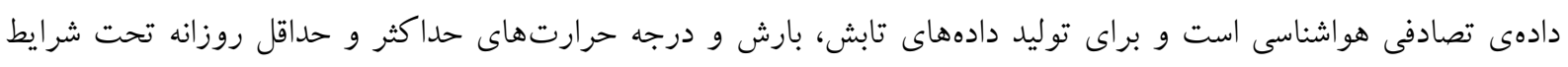

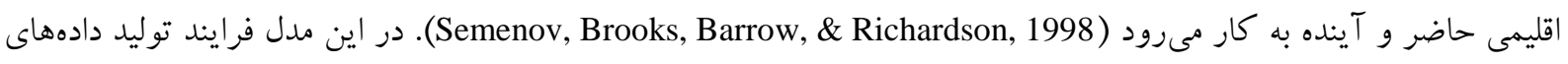

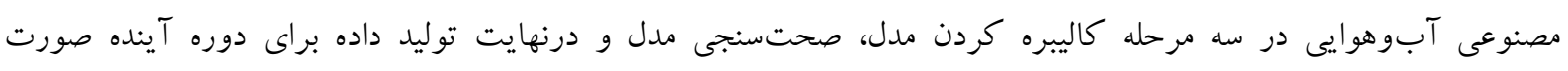

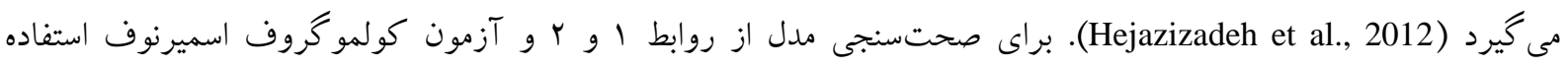

$$
\begin{aligned}
& \text { RMSE }=\sqrt{\frac{\sum_{i=1}^{n}\left(\mathrm{o}_{\mathrm{i}}-\mathrm{e}_{\mathrm{i}}\right)^{2}}{\mathrm{n}}} \\
& \text { رابطه (1) جذر ميانكين مربعات خطا } \\
& \text { MSE }=\frac{\sum_{i=1}^{n}|| \mathrm{o}_{\mathrm{i}}-\mathrm{e}_{\mathrm{i}} \mid}{\mathrm{n}} \\
& \text { رابطه (r) ميانگين قدر مطلق انحرافات }
\end{aligned}
$$

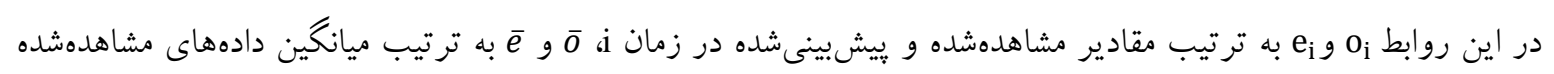

و ييشينى شده و n تعداد مشاهدات مىباشد.

1 Long Ashton Research Station Weather Generator 
بيشينى تاريخ هاى آغاز و يايان يخبندانهاى استان اردبيل با استفاده از خروجى ... I9V/

در شبيهسازى كه براى دورههاى آينده صورت مى گيرد، با توجه به نبود دادههاى واقعى براى آن دورهها؛ امكان بررسى

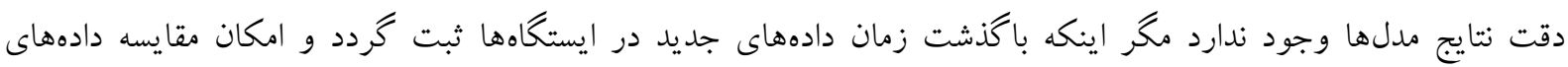
شبيهسازى شده با دادههاى واقعى مهيا شود. در اين يزوهش دادههاى خايه مورداستفاده تا سال ·r.1 مىباشد و شبيهسازى

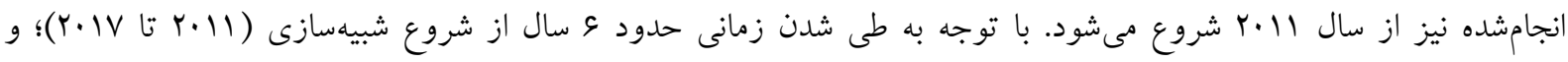

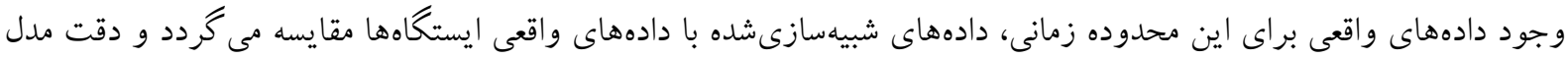

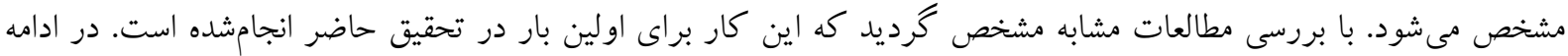

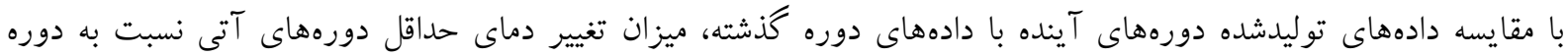

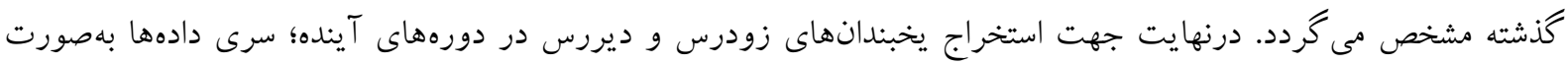

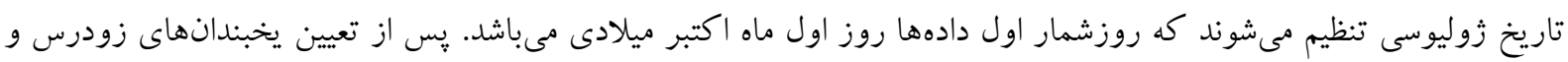

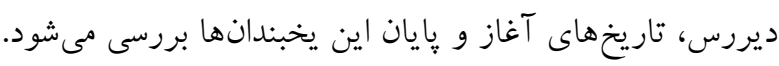

\section{يافتهاى يزوهش انتخاب مدل گردش عمومى جو} براى انتخاب مدل كارآمد كردش عمومى جو خروجى دادههاى 9 مدل اقليمى با دادههاى متناظر پايه ايستخاهها مقايسه

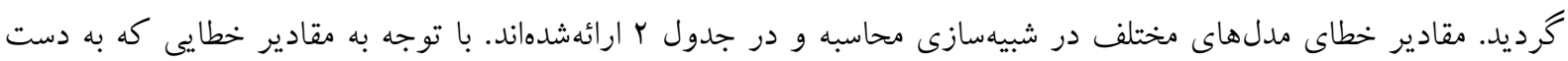

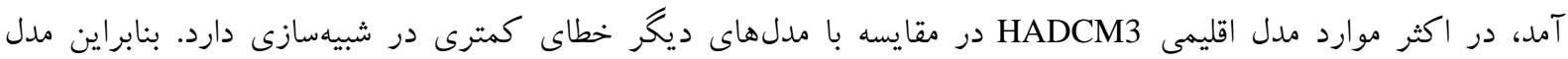

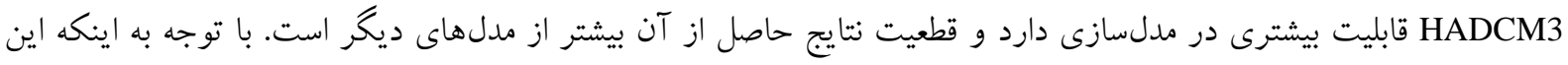

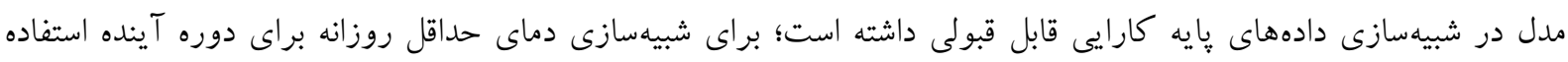
كرديد.

جدول r- مقادير خطاى مدل ها در شبيهسازى دماى حداقل روزانه دورههاى كذشته در ايستكاهها

\begin{tabular}{|c|c|c|c|c|c|c|}
\hline \multicolumn{2}{|c|}{ خلخال } & \multicolumn{2}{|c|}{ اردبيل } & \multicolumn{2}{|c|}{ يارس آباد } & \\
\hline RMSE & MSE & RMSE & MSE & RMSE & MSE & \\
\hline$r / q$. & $\cdot / 1 \Lambda$ & $r / T Y$ & $1 / \mathrm{VV}$ & $r / 1 \Delta$ &.$/ 94$ & BCM2.0 \\
\hline$f / \pi$ &.$/ \mathrm{V}$ & r/Ar & $r / 1 \Delta$ & $F / V \Delta$ & $1 / T F$ & CNRMCM3 \\
\hline$r / \Lambda T$ & $\cdot / 48$ & f/ar & $\Delta / 9 V$ & $r / T r$ & $f / \pi r$ & CSIROMK 3.0 \\
\hline $1 / .8$ & $\cdot / 1 f$ & $\Delta / 9 \pi$ & $1 / \Delta 9$ & $1 / .8$ &.$/ 1 F$ & HADCM3 \\
\hline$f / \mu \Lambda$ & $\cdot / \Delta \Delta$ & $r / F r$ & $1 / \mathrm{WV}$ & $F / F V$ & $1 / \cdot v$ & FGOALS-g1.0 \\
\hline$r / / 9$ & 每 & $r / \Delta F$ & $0 / 49$ & $\Delta / q$. & $\cdot|r|$ & CGCM3T63 \\
\hline $10 / \wedge 9$ & $\cdot / F V$ & $\mid f / g r$ & $F r / q 9$ & $r / \Lambda$ & $\cdot / \pi V$ & GISS-AOM-Mean \\
\hline $8 / .9$ & $\cdot / 4 F$ & S/FV & $|s / v|$ & $1 / 1 \pi$ & / & IPSLCM4 \\
\hline$r / s$. & 每/ & $11 / A f$ & $r q / \mu$. & $\Delta / \mu l$ & $1 / T V$ & INMCM3.0 \\
\hline
\end{tabular}

مدل HADCM3 يكى از مدلهاى سهبعدى جفت شده كردش عمومى جوى - اقيانوسى است و توسط مركز تحقيقات و

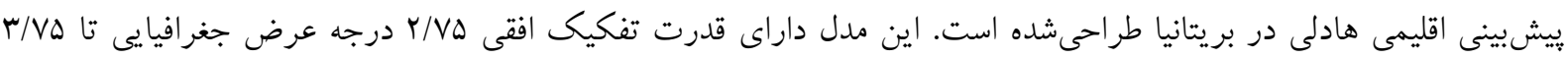

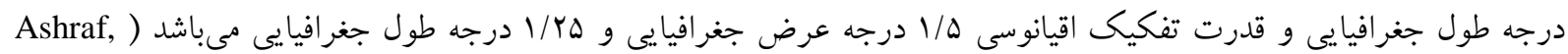
Mousavi Bighi, Kamali, \& Davari, 2011 


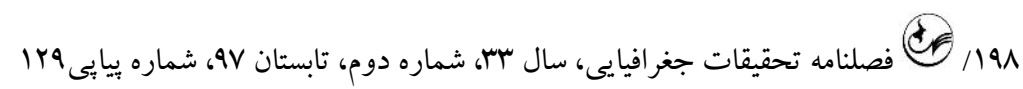
جمعيت جهانى، غلظت

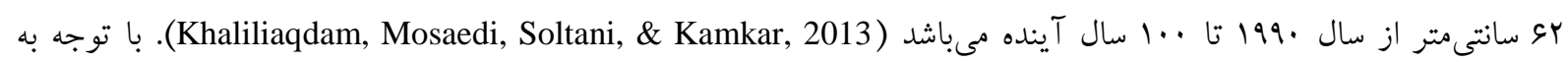

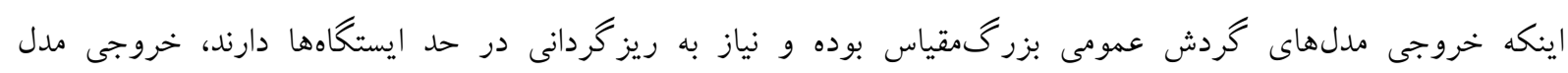
LARS-WG با مدلهـ LADCM3

صحت سنجى مدل LARS-WG

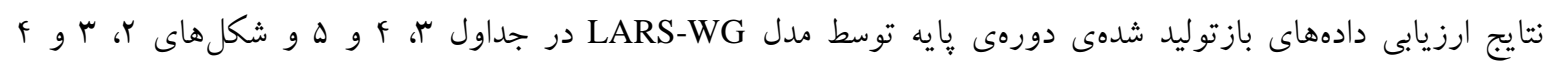

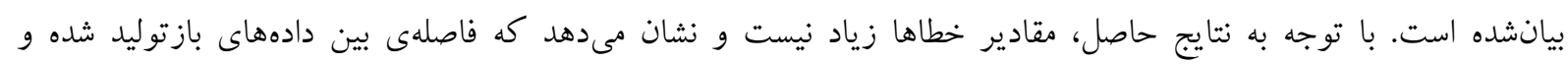

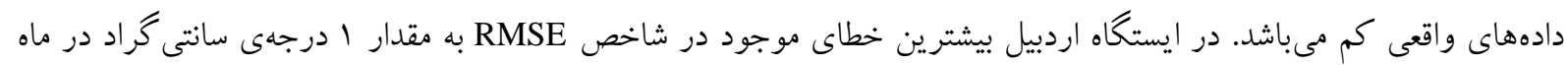

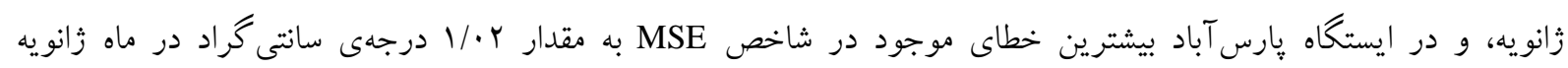

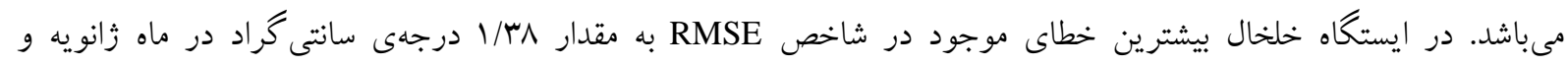
بعداز آن ب/ ا درجهى سانتى گراد در ماه دسامبر مى دباشد.

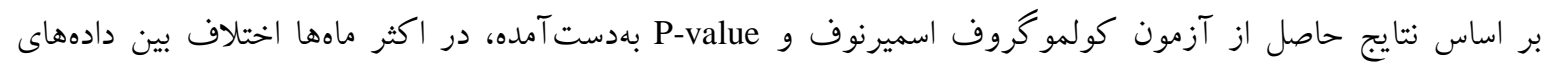
بازتوليد شده و مشاهدهده در سطح اطمينان 99/ • و سطح معنى دارى 1.

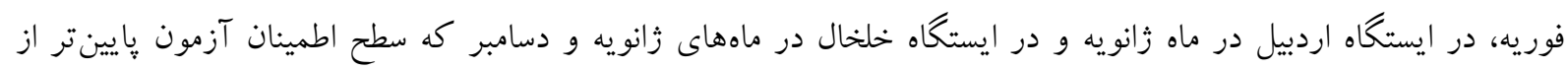

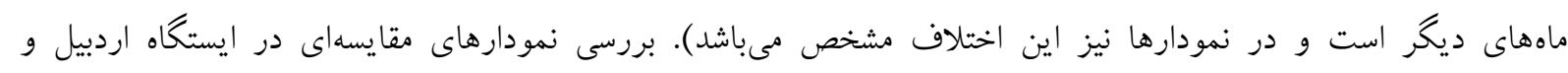
קارس آباد، بيانگر دقت بسيار بالاى مدل مى باشد. اما در ايستخاه خلخال در ماههاى سرد سال خطاى مدل بيشتر از دو ايستخاه ديخر است. باين حال مقدار خطا خندان قابل توجه نيست.

جدول r- مقادير MSE RMSE و آزمون KS و P-value آن در ايستغاه پارس آباد

\begin{tabular}{|c|c|c|c|c|c|c|c|c|c|c|c|c|}
\hline دسامبر & نوامبر & اكتبر & ستِامبر & آكوست & جولاى & زوئن & مى & آوريل & مارس & فوريه & زرانويه & \\
\hline . & . & $\cdot / r \mid$ & / RY &.$/ . \mu$ & $\cdot / \cdot f a$ & .110 &.$/ 1 f$ & $\cdot|\mu|$ & $\cdot / 1 \Lambda$ & $\cdot / \mathrm{Tf}$ & $\cdot / 49$ & RMSE \\
\hline.$/ 18$ &.$/ .4$ &.$/ \cdot r$ &.$/ .1$ &.$/ \cdots 1$ & $\cdot / \ldots r$ & $\cdot \cdots 1$ &.$/ .1$ &.$/ \cdot \mu$ &.$/ .4$ & . AT & $1 / . r$ & MSE \\
\hline .11 .8 & .11 .8 & $\cdot / \cdot \Delta r$ & .11 .8 &.$/ \Delta r$ & .11 .8 & .11 .8 & .11 .8 &.$/ \Delta r$ &.$/ \Delta \mu$ & $\cdot / 1 \Delta \Lambda$ & .11 .8 & KS statistic \\
\hline ./११८ &.$/ 991$ & 1 &.$/ 991$ & 1 &.$/ 991$ &.$/ 991$ &.$/ 991$ & 1 & 1 &.$/ 914$ & $\cdot / 991$ & P-value \\
\hline
\end{tabular}

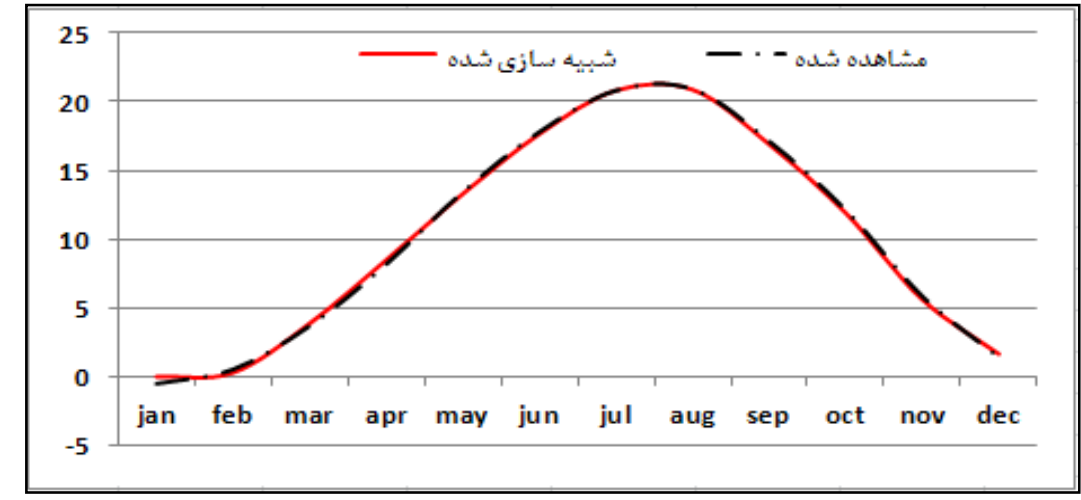

شكل r- نمودار مقايسهاى مقادير بازتوليد شده و مشاهدهاى ميانغين دماى حداقل در ايستغاه هارس مقآباد 
بيشينى تاريخ هاى آغاز و بايان يخبندانهاى استان اردبيل با استفاده از خروجى ... /99

جدول ع- مقادير MSE ، RSE و آزمون KS و P-value آن در ايستكاه اردبيل

\begin{tabular}{|c|c|c|c|c|c|c|c|c|c|c|c|c|}
\hline دسامبر & نوامبر & اكتبر & سيتامبر & آكوست & جولاى & زوئن & مى & آوريل & مارس & فوريه & زانويه & \\
\hline.$/ 1$ & $\cdot / 11$ & $.1 \cdot 9$ & . & $\cdot / T \Delta V$ & $\cdot 119$ & $\cdot / r r$ & $\cdot|r|$ & $\cdot / \cdot \mathrm{VV}$ & 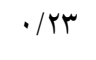 & $\cdot / \cdot 0$ & 1 & RMSE \\
\hline$\cdot / \cdot r$ & ع &.$/ 18$ & $\cdot / \cdot r$ &.$/ \cdot r$ & $.1 \cdot 18$ & 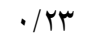 & $\cdot / \cdot r$ & $\cdot / \cdot r$ & $\cdot / 1 \wedge$ & $\cdot / \cdot 1 r$ & $\cdot / 18$ & MSE \\
\hline$\cdot 11 \cdot 8$ & $\cdot / \cdot \Delta r$ & •/. & $\cdot / 1 \cdot 9$ & •/. & $\cdot / 1 \cdot 8$ & $\cdot / \cdot \Delta r$ & $\cdot / 1 \cdot 0$ & $\cdot / 1 \cdot 8$ & $\cdot / 1 \cdot 0$ & $\cdot / 1 \cdot 9$ & $\cdot / \mid \Delta \wedge$ & KS statistic \\
\hline.$/ 991$ & 1 & 1 & $\cdot / 991$ & 1 &.$/ 991$ & 1 &.$/ 999$ & $\cdot / 991$ & $\cdot / 999$ &.$/ 991$ &.$/ 91 r$ & P-value \\
\hline
\end{tabular}

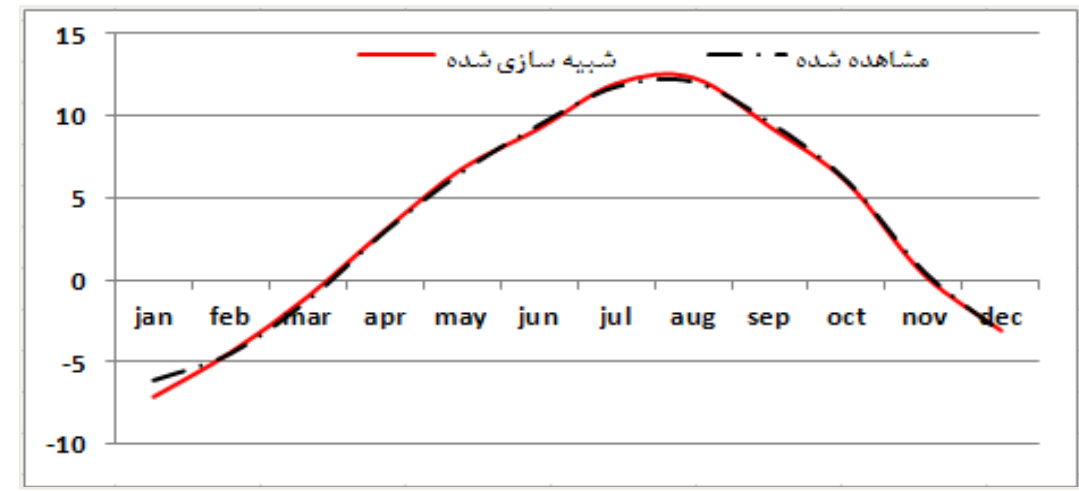

شكل r- نمودار مقايسهاى مقادير بازتوليد شده و مشاهدهاى ميانغين دماى حداقل در ايستغاه اردبيل

جدول 0- مقادير MSE و MSE و آزمون RS و P-value آن در ايستغاه خلخال

\begin{tabular}{|c|c|c|c|c|c|c|c|c|c|c|c|c|}
\hline دسامبر & نو امبر & اكتبر & سيتامبر & آكوست & جولاى & زوئن & مى & آوريل & مارس & فوريه & زانويه & \\
\hline $1 / r T$ & / /EY & $\cdot / \Delta S$ & .1 .48 &.$/ .8$ & .1 .18 & $\cdot / r$ & $\cdot / \cdot V$ & $\cdot / \cdot r \Delta$ & $\cdot / \Delta T$ & $\cdot / V \Delta$ & $1 / \Gamma \wedge$ & RMSE \\
\hline$\cdot / r Y$ & $\cdot / r \varepsilon$ & $\cdot / 1 \varepsilon$ & $\cdot \cdot \cdot \Delta V$ & $\cdot / \cdots \omega$ & $\cdot / \cdot \cdot 1$ &.$/ \cdot r$ &.$/ \cdot 1$ &.$/ \cdot 1$ & $\cdot / r Y$ & $\cdot 11$ & $\cdot / 18$ & MSE \\
\hline$\cdot / \mid \Delta \wedge$ & $\cdot 11 \cdot 9$ & $\cdot / 1 \cdot 8$ & •/ $/ \Delta r$ & $\cdot / 1 \cdot 0$ & $\cdot / 1 \cdot 0$ & $\cdot / 1 \cdot \Delta$ & •/. & $\cdot 11 \cdot 9$ & r. & $\cdot / 1 \cdot \Delta$ & $\cdot / 1 \Delta \Lambda$ & KS statistic \\
\hline.$/ 91 r$ &.$/ 991$ &.$/ 991$ & 1 &.$/ 999$ &.$/ 999$ &.$/ 999$ & 1 &.$/ 991$ & 1 &.$/ 999$ &.$/ 91 r$ & P-value \\
\hline
\end{tabular}

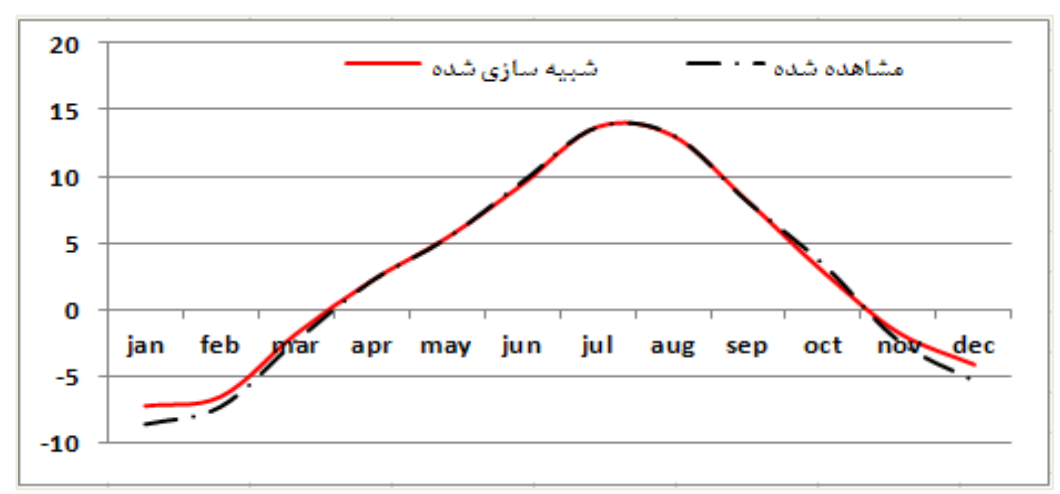

شكل ع- نمودار مقايسهاى مقادير بازتوليد شده و مشاهدهاى

ميانكين دماى حداقل در ايستغاه خلخال 


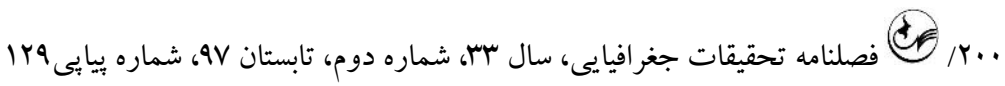
با توجه به كارايى مدل LARS-WG در بازتوليد ميانگين دماى حداقل براى دورهى پايه، خروجى مدل HADCM3 با مدل ARS-WG

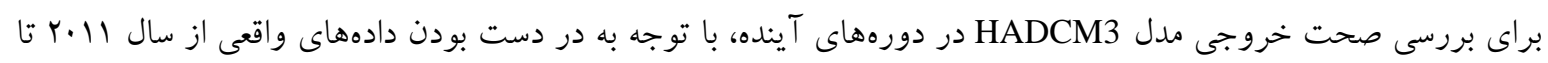
عا.با؛ دادههاى شبيهسازىشده براى اين بازه زمانى با دادههاى واقعى مقايسه گرديد. نتايج حاصل در شكل ه نشان دادهشده است. همانطور كه مشخص مىباشد ميانخين ماهانه دادهاى شبيهسازىشده تفاوت زيادى با دادهاى واقعى ايستخاهها ندارد و توانايى مدل قابلقبول مىباشد (بهجز در ايستخاه خلخال كه در دوره سرد اختلاف دادهها زياد مىباشد).

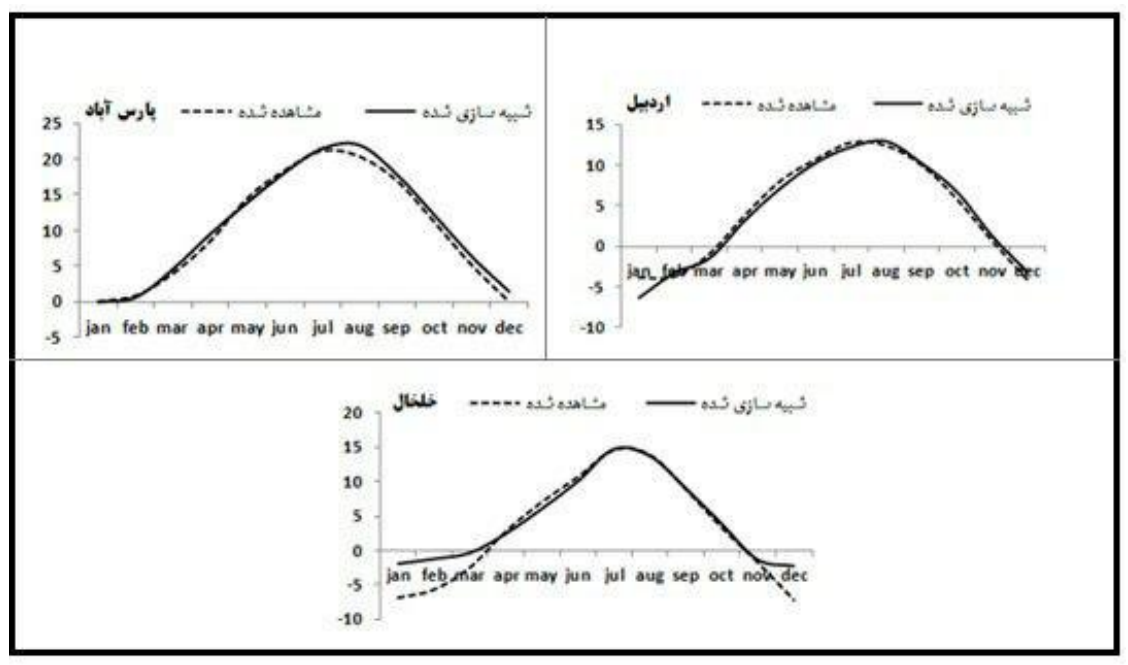

شكل 0- مقايسه ميانكين دماى حداقل ماهانه دادههاى شبيهسازىشده

و دادههاى مشاهدهشه در دوره 11 • r تا 17 .

براى مشخص شدن ميزان تغييرات دما در دورههاى آينده نسبت به دورهى كذشته، ميانخين دماى ماهانه در دورهها باهم مقايسه شدند (شكل ع). طورى كه در شكل ع مشاهده مىشود در هر سه دوره آينده مقدار دما نسبت به كذشته افزايش خواهد يافت. در ايستخاه خلخال ميزان افزايش دماى حداقل در ماههاى سرد سال بيشتر خواهد بود. در بخش صحتسنجى مدل بيان شد كه در ايستكاه خلخال در ماههاى سرد سال خطاى مدل بيشتر از دو ايستخاه ديخر است. در دادههاى شبيهسازىشده نيز در اين ماهها ميزان دما با افزايش زيادى بر آورد شده است. بنابراين احتمال وجود خطا در اين بر آوردها وجود دارد.

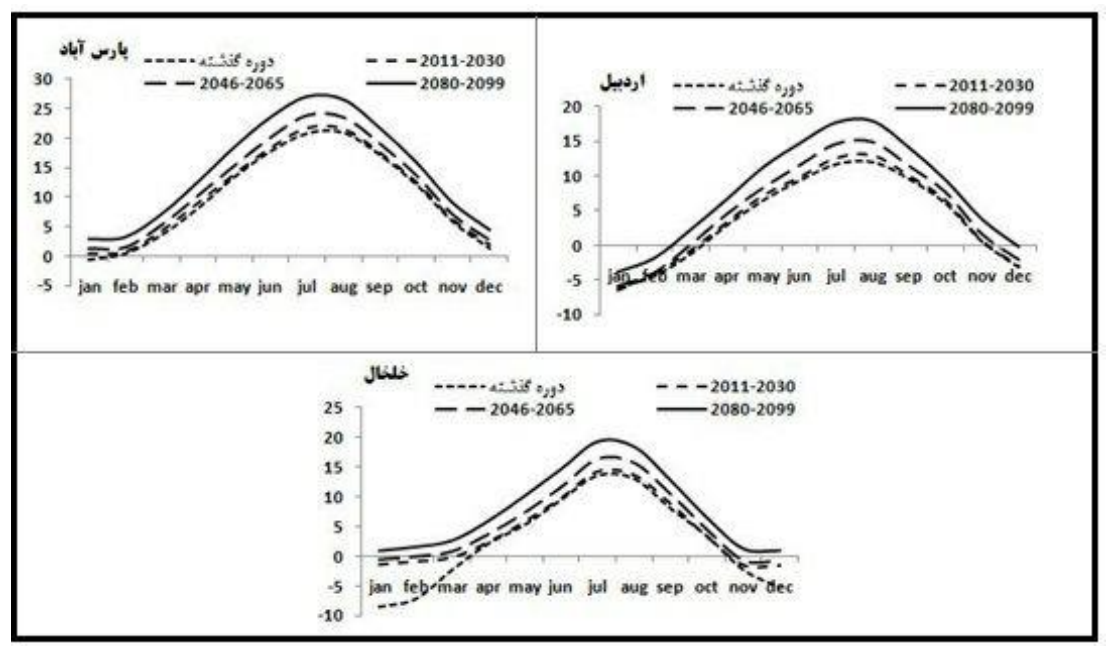

شكل 7- مقايسه ميانكين دماى حداقل ماهانه دورههاى آينده با دوره كذشته 
ֶِ از شبيهسازى دماى حداقل روزانه براى دورههاى آينده، براى تحليل تاريخهاى آغاز و پايان يخبندانها، سرى دادهها

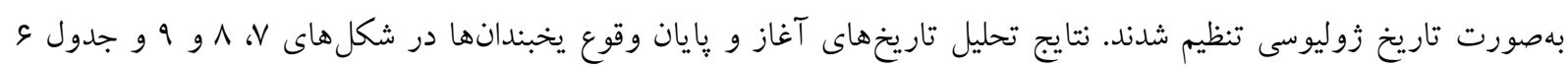

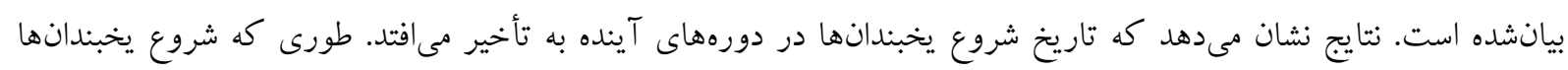

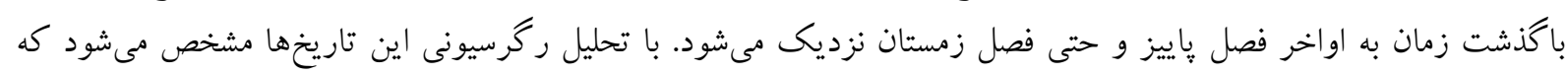

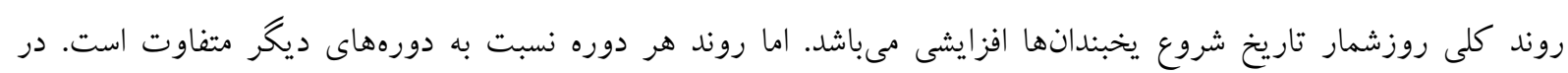

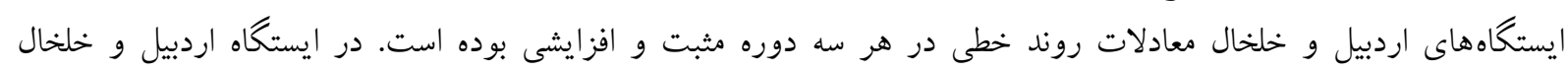

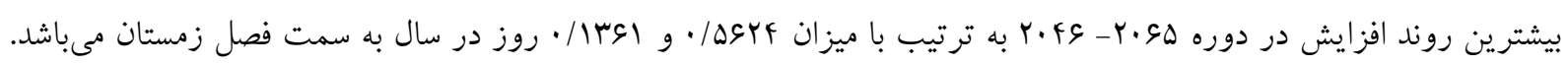

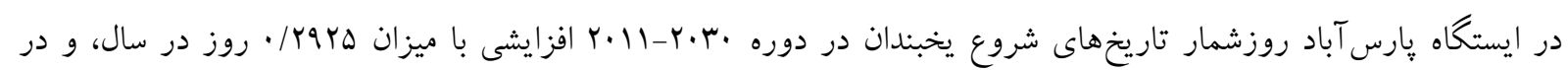

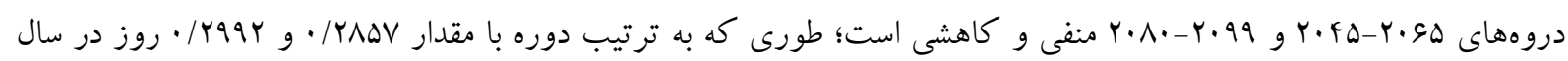

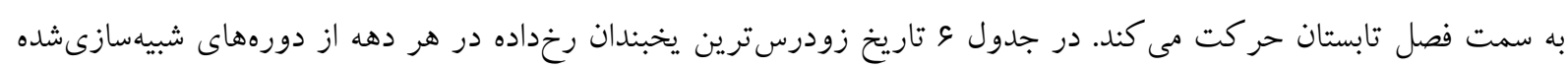

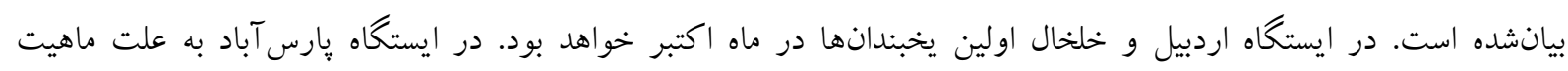
كرمسيرى آن، تاريخهاى مذكور در ماه نوامبر و دسامبر بر آورد شده است.

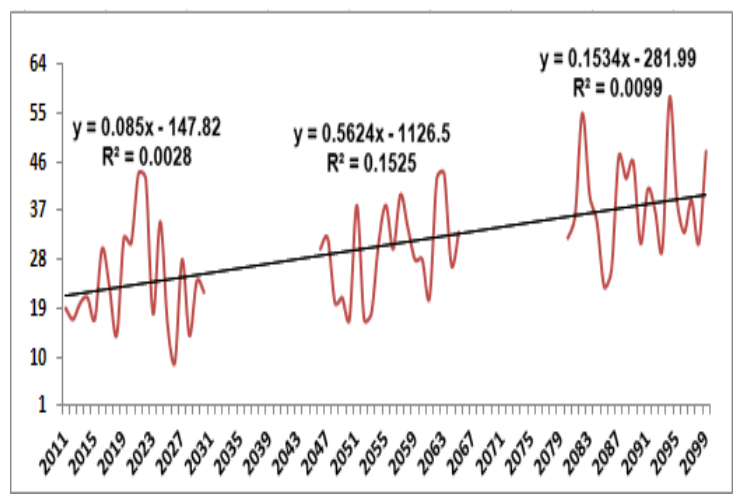

شكل ^- نوسان و روند تغييرات سرى زمانى روزشمار آغاز يخبندانهاى ايستغاه اردييل در دورههاى شبيهسازى لشده

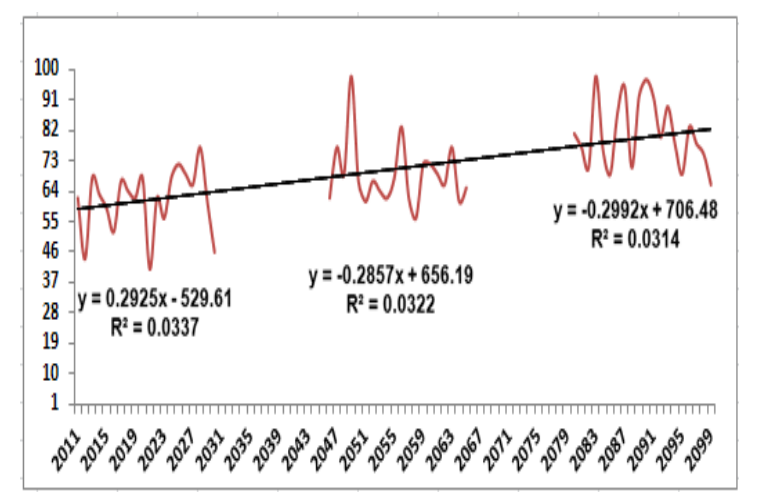

شكل Y- نوسان و روند تغييرات سرى زمانى روزشمار آغاز يخبندانهاى ايستَاه هارس آباد در دورههاى شبيهسازىشده

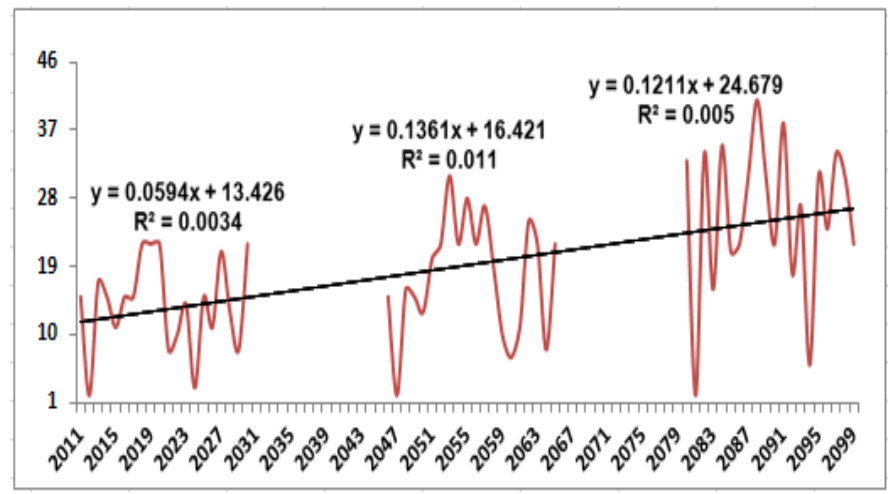

شكل 9- نوسان و روند تغييرات سرى زمانى روزشمار آغاز

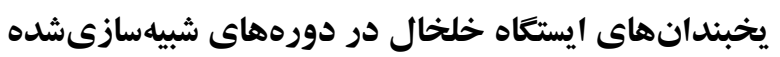




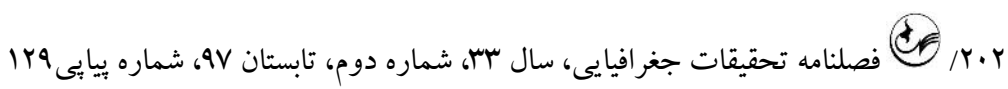
جدول 7- تاريخ زودرسترين يخبندان رخداده در هر دها از دورههاى شبيهسازىشده

\begin{tabular}{|c|c|c|c|}
\hline خلخال & اردبيل & يارس آباد & دهههاى دوره شبيهسازى \\
\hline r اكتبر & fl | اكتبر & سانوامبر & $r \cdot 11-r \cdot r \cdot$ \\
\hline f اكتبر f & 9 اكتبر & · انوامبر & $r \cdot r l-r \cdot r \cdot$ \\
\hline ك اكتبر & ا اكتبر & • س نو امبر. & $r \cdot r \varepsilon-r \cdot \Delta \Delta$ \\
\hline اكتبر V V l V & | | اكتبر & ل فr نوامبر & $r \cdot \Delta G-r \cdot S \Delta$ \\
\hline ا & سץ اكتبر & ^ دسامبر & $r \cdot \Lambda \cdot-r \cdot \wedge q$ \\
\hline ع اكتبر & 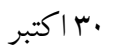 & F أ دسامبر & $r \cdot q \cdot-r \cdot 99$ \\
\hline
\end{tabular}

تحليل تاريخهاى پايان يخبندان بررسى سرى زمانى گايان يخبندانها در دورههاى شبيهازىشده نشان مىدهد كه آخرين يخبندانها باكذشت زمان به سمت فصل زمستان عقبنشينى مى كند. با بررسى تحليل ركرسيونى اين تاريخها مشخص مىشود كه روند كلى روزشمار تاريخها كاهشى مى باشد. اما روند هر دوره نسبت به دوره ديخر متفاوت است. در ايستخاه يارسآباد معادلات روند خطى در دوره

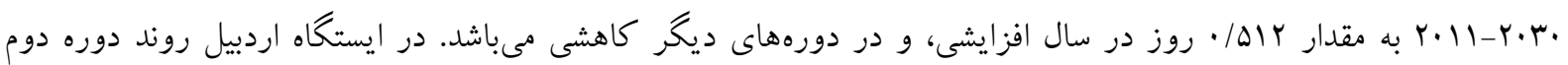

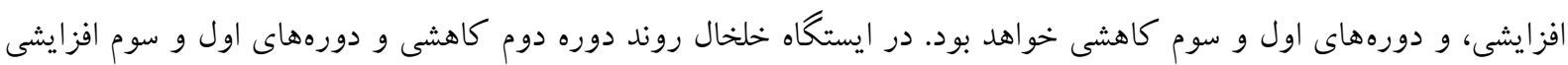
خواهند بود. در جدول V تاريخ ديررسترين يخبندان رخداده در هر دهه از دورههاى شبيهازى بيانشده است. در ايستخاه اردبيل و خلخال آخرين يخبندانها در ماههاى آوريل و مى، رخ خواهد داد. در ايستخاه يارس آباد در اكثر موارد يخبندانها در

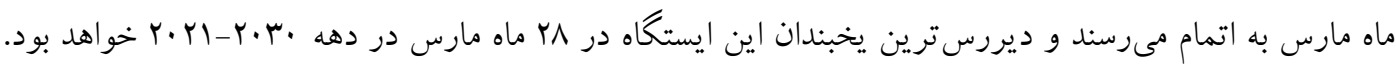

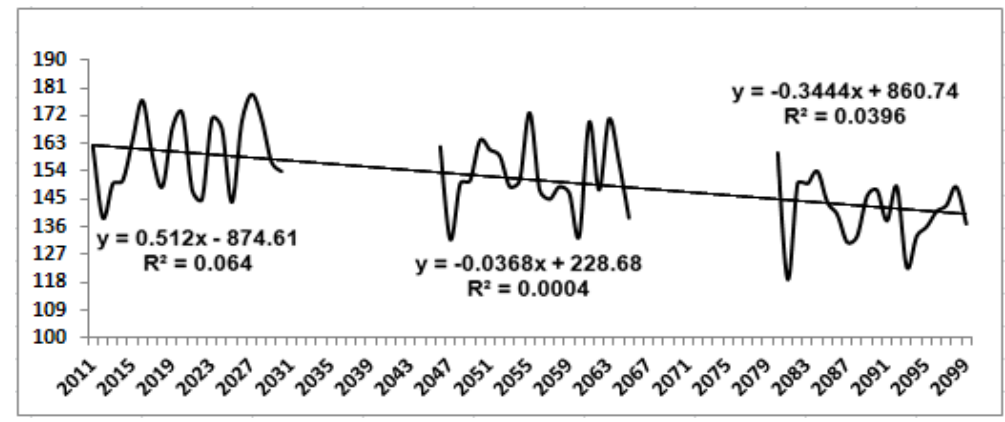

شكل • ا - نوسان و روند تغييرات سرى زمانى روزشمار پايان يخبندانهاى ايستغاه هارس آباد در دورههاى شبيهسازى شده

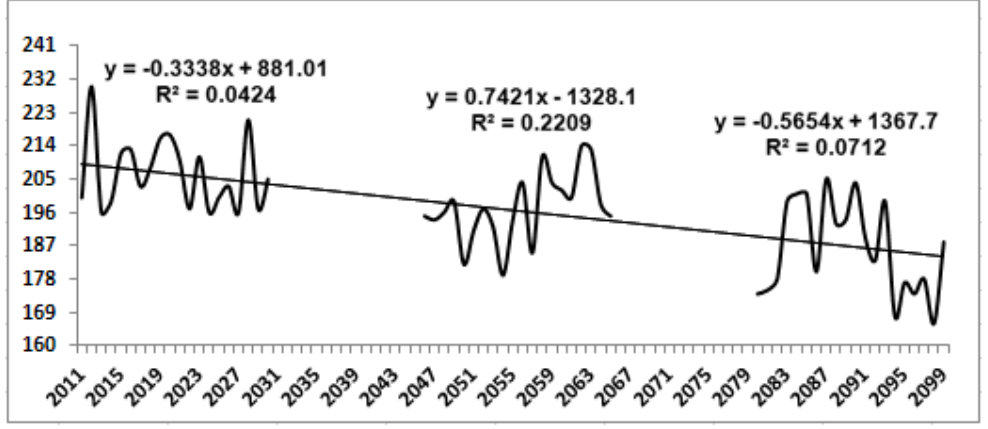

شكل I| - نوسان و روند تغييرات سرى زمانى روزشمار يايان يخبندانهاى ايستغاه اردبيل در دورههاى شبيهسازى 


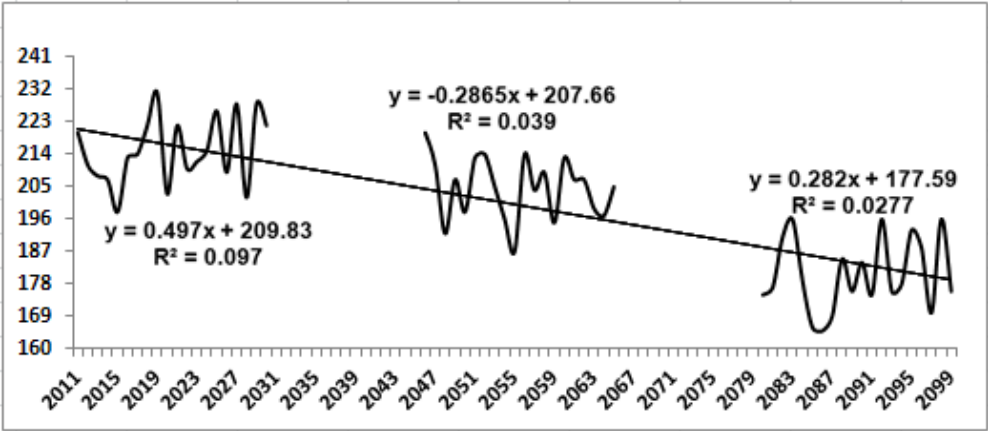

شكل ז ا - نوسان و روند تغييرات سرى زمانى روزشمار يايان يخبندانهاى ايستغاه خلخال در دورههاى شبيهسازى رونده

جدول Y- تاريخ ديررسترين يخبندان رخداده در هر دهل از دورههاى شبيهسازىشده

\begin{tabular}{|c|c|c|c|}
\hline خلخال & اردبيل & يارس آباد & دهه هاى دوره شبيهسازى \\
\hline (19 & 11 1 مى & ع مارس & $r \cdot 11-r \cdot r$. \\
\hline 16 أمى & 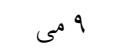 & 1 Y مارس & $r \cdot r I-r \cdot r$. \\
\hline ه م مى & IV آوريل & r T مارس & $r \cdot F S-r \cdot \Delta \Delta$ \\
\hline یr آوريل & r & · r مارس r & $r \cdot \Delta \varepsilon-r \cdot s \Delta$ \\
\hline سا آوريل & سץ آوريل & 9 مارس & $r \cdot \Lambda \cdot-r \cdot \Lambda q$ \\
\hline سا آوريل & r r آوريل & عب فوريه & $r \cdot q \cdot-r \cdot q q$ \\
\hline
\end{tabular}

نتيجل كيرى

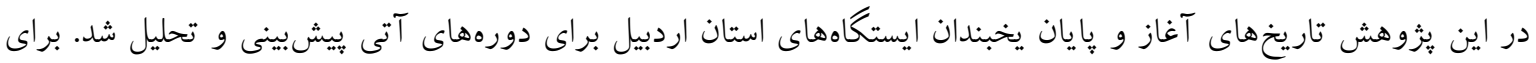

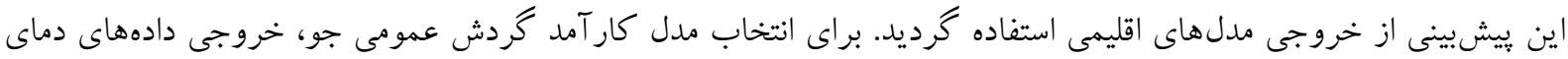

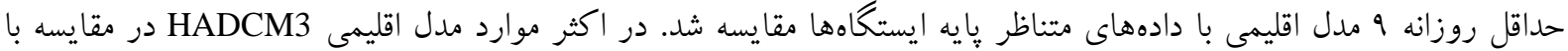

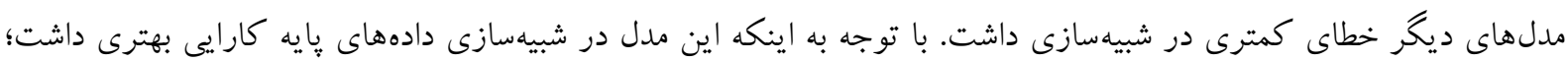

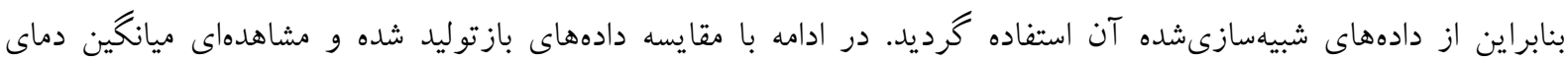

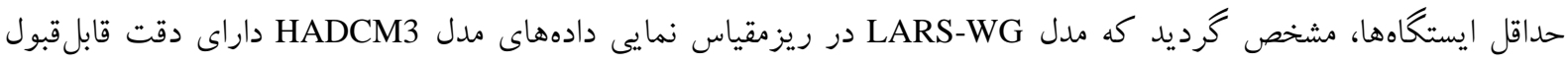

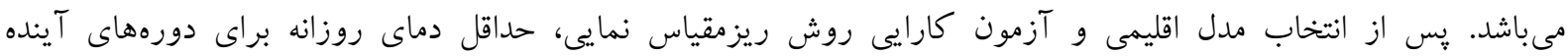

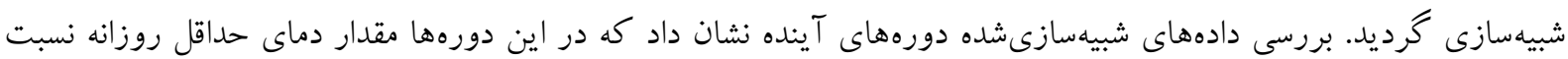

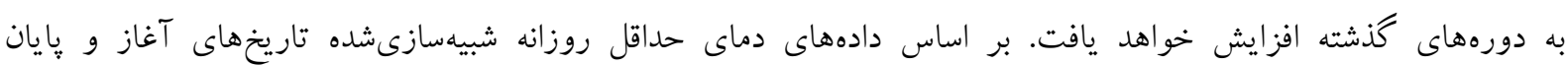

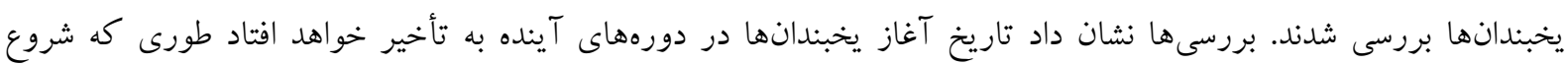

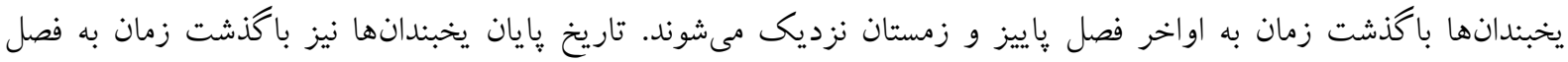

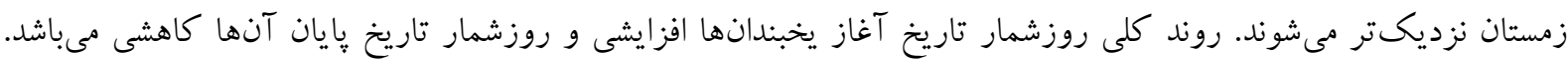

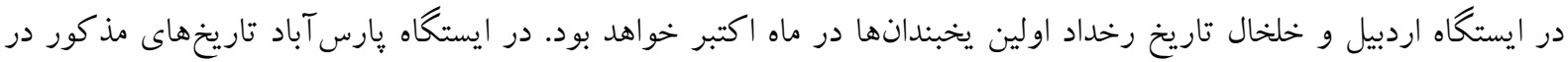

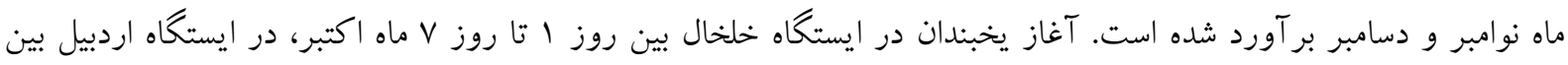

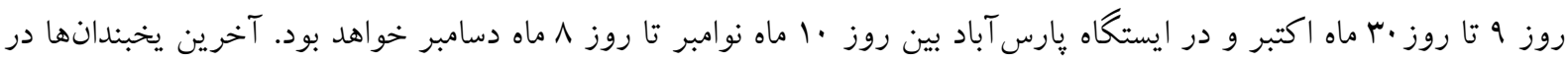

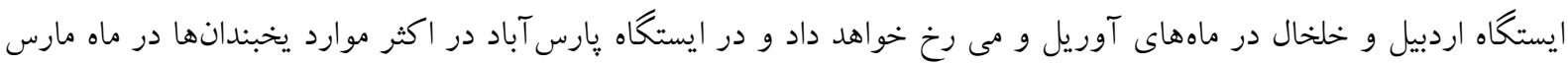

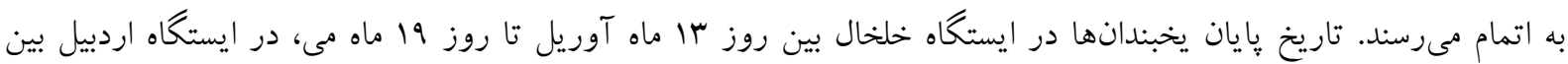

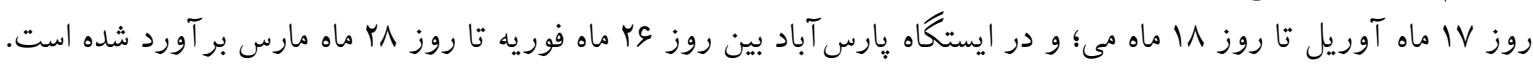




$$
\begin{aligned}
& \text { Y.Y.F } \\
& \text { نتايج نشان مى دهد طول دورهى يخبندان ايستخاههاى استان اردبيل در دورههاى آينده كوتاهتر، و طول دوره رشد بيشتر }
\end{aligned}
$$

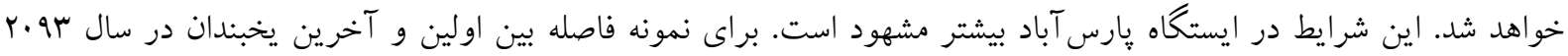

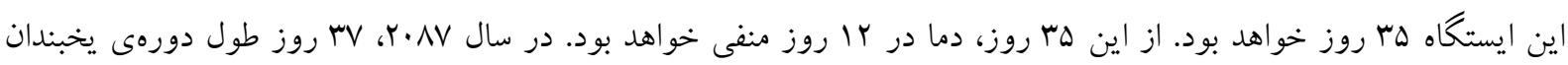

$$
\begin{aligned}
& \text { خواهد بود كه در } 9 \text { روز آن دماى منفى رخ مى ئدهد. نتايج يزوهش حاضر همانند نتايج بسيارى از تحقيقات نشاندهنده تغييرات }
\end{aligned}
$$

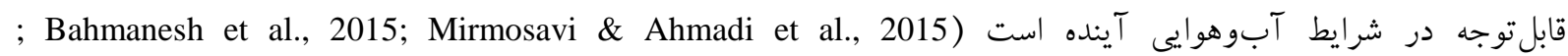$$
\text { (Hosseinbabaii, 2011; Modaresi et al., 2011; Steele-Dunne et al., } 2008
$$$$
\text { تاريخهاى آغاز و یايان يخبندانها در ايستخاههاى استان اردبيل تغيير قابلتوجهى نسبت به دوره كذشته خواهند داشت. بنابراين }
$$$$
\text { لازم است در برنامهريزىهاى مختلف بهويزه در ارتباط با مسائل كشاورزى اين موارد موردتوجه قرار كيرد. }
$$

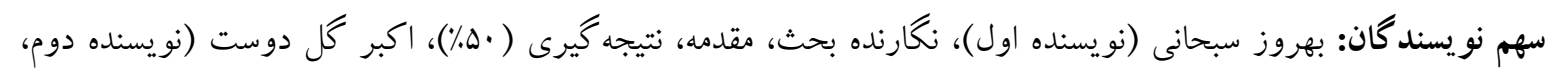$$
\text { مسئول)، نخارنده روششناسى، تحليل كر آمارى ( •ه٪) }
$$$$
\text { منابع و مآخذ }
$$

Ababaei, B., Sohrabi, T., Mirzaei, F., Reza Verdi-Nejad, V., \& Karimi, B. (2010). Effect of climate change on wheat yield and its risk analysis (Case study: Isfahan plain area). Knowledge of Water and Soil, 20.1(3), 135-150. (Persian)

Abbasi, F., Babaeian, A., Melboosi, S., Asmari, M., \& Mokhtari, L. G. (2012). Estimation of Iran's climate change in the coming decades (2025-2100 BC) using an explicit microscale of data from the general circulation model of barley. Geographical Researches Quarterly Journal, 27(1), 205-230. (Persian)

Ahmadi, A., Khorramian, A., \& Safavi, H. R. (2015). Investigating the effects of climate change on the process of snow to runoff, Case study: Zayandehrood Basin. Iran Water Resources Research, 11(2), 70-82. (Persian)

Aliyari, M., Teshnelab, M., \& Khaki, A. (2008). Short-term prediction of air pollution with the help of multilayered perceptron neural networks, latency line, gamma and ANFIS with PSO-based teaching methods. Journal of Control, 2(1), 1-19. (Persian)

Andersen, H. E., Kronvang, B., Larsen, S. E., Hoffmann, C. C., Jensen, T. S., \& Rasmussen, E. K. (2006). Climate-change impacts on hydrology and nutrients in a Danish lowland river basin. Science of the Total Environment, 365(1-3), 223-237. [DOI:10.1016/j.scitotenv.2006.02.036]

Ashofte, P., \& Bozorg Hadad, O. (2015). Assessments of risk-based of crops water requirement under climate change using AOGCMs. Journal of Range and Watershed Managment, 68(3), 441-457. (Persian)

Ashraf, B., Mousavi Bighi, M., Kamali, G., \& Davari, K. (2011). Preliminary estimation of sugar beet juice demand in the period 2030-2011 by using climatic data simulated by LARS-WG micro-scaling model. Journal of Soil and Water, 25(5), 1184-1196. (Persian)

Babaeian, A., \& Kouhi, M. (2011). Evaluation of agricultural climate indices under climate change scenarios in selected stations in Khorasan Razavi. Journal of Water and Soil, 26(4), 953-967. (Persian)

Bahmanesh, J., Azad Talatape, N., Montaseri, M., Rezaei, H., \& Khalili, K. (2015). Effect of climate change on reference evapotranspiration, rainfall shortage and air vapor pressure in Urmia. Knowledge of Water and Soil, 25(2), 79-91. (Persian)

Dai, A., Fung, I. Y., \& Del Genio, A. D. (1997). Surface observed global land precipitation variations during 1900-88. Journal of Climate, 10(11), 2943-2962. [DOI:10.1175/1520-0442(1997)0102.0.CO;2]

Darand, M., \& Masoodian, S. A. (2015). Waiting time of frost occurrence over Iran. Geographical Researches Quarterly Journal, 30(1), 81-94. (Persian)

Ekström, M., Fowler, H. J., Kilsby, C. G., \& Jones, P. D. (2005). New estimates of future changes in extreme rainfall across the UK using regional climate model integrations. 2. Future estimates and use in impact studies. Journal of Hydrology, 300(1), 234-251. [DOI:10.1016/j.jhydrol.2004.06.019]

Elguindi, N., \& Giorgi, F. (2006). Simulating multi-decadal variability of Caspian Sea level changes using regional climate model outputs. Climate Dynamics,26(2-3),167-181.[DOI:10.1007/s00382-005-0077-5]

Hejazizadeh, Z., Fatahi, A., Masoumeh Bavani, A., \& Naserzadeh, M. H. (2012). Evaluating the effect of climate change on flood hydrograph in future periods Case study: Bakhtiari basin. Geography, 10(34), 5-24. (Persian)

Hejazizadeh, Z., \& Naserzadeh, M. H. (2005). Calculating and analyzing the continuity of freezing clocks using delphi language programming. Geographical Researches Quarterly Journal, 20(1), 139- 150. (Persian) 
بيشينى تاريخهاى آغاز و بايان يخبندانهاى استان اردبيل با استفاده از خروجى ... /ه.r.

Kazemirad, L., \& Mohammadi, H. (2015). Evaluation of the proper model of atmospheric circulation for forecasting climate change in Guilan province. Geography and Environmental Hazards, 4(16), 55-74. (Persian)

Khaliliaghdam, N., \& Soltani, A. (2009). Assessment of climate change during last fifty years in Urmia. Journal of Water and Soil Conservation Studies, 16(4), 141-151. (Persian)

Khaliliaqdam, N., Mosaedi, A., Soltani, A., \& Kamkar, B. (2013). Evaluation of ability of LARS-WG model for simulating some weather parameters in Sanandaj. Journal of Soil and Water Conservation Research, 19(4), 85-102. (Persian)

Khosravi, M., Tavousi, T., \& Zohraei, A. (2015). Simulation of climate change in Sistan and Baluchestan for the period 2009-2040 by using downscaling the data of global circulation model. Geographical Researches Quarterly Journal, 30(3), 185-205. (Persian)

Livingston, D. P., Tuong, T. D., Isleib, T. G., \& Murphy, J. P. (2016). Differences between wheat genotypes in damage from freezing temperatures during reproductive growth. European Journal of Agronomy, 74, 164-172. [DOI:10.1016/j.eja.2015.12.002]

Mahdi zadeh, M., Meftah Halghi, M., Seyyed Ghasemi, S., \& Mosaedi, A. (2011). Investigating the Effect of Climate Change on Precipitation in Golestan Dam Basin. Journal of Water and Soil Conservation, 18(3), 117-132. (Persian)

Mahmoudi, P., Khosravi, M., Mas'udiyan, S. A., \& Alijani, B. (2015). Relationship between tele connection patterns and Iran's pervasive frosts. Geography and Development, 13(40), 175-193. (Persian)

Mahmoudi, P., Khosravi, M., Masoudian, S. A., \& Alijani, B. (2013). Atlas of climatology of Iran's statistical characteristics of glaciers. Geographical Researches Quarterly Journal, 28(4), 55-66. (Persian)

Massoudian, S. A., \& Darand, M. (2015). Investigating the trend of the number of freezing days in Iran. Geography and Development, 13(39), 49 - 60. (Persian)

Mirmosavi, S. H., \& Hosseinbabaii, M. (2011). Study of temporal-spatial distribution of the probability of freezing in Zanjan province. Geography Magazine and Environmental Planning, 22(3), 167- 184. (Persian)

Modaresi, F., Araghinejad, S., Ebrahimi, K., \& Kholghi, M. (2011). Investigating the effect of climate change on annual discharge of rivers (Case study: Gorganrood River). Journal of Water and Soil, 25(6), 13651377. (Persian)

Mozaffari, G. (2013). Investigation of the process of beginning and end dates of zero and five degrees Celsius temperatures at Iran's selected stations. Geographical Researches Quarterly Journal, 28(2), 93-111. (Persian)

Omidvar, K., \& Aslani, A. (2014). Analyzing and analyzing the temporal and spatial changes of glaciation in Zayandehrud Basin. Geographical Researches Quarterly Journal, 29(114), 147-164. (Persian)

Osati, K., Salajegheh, A., Mahdavi, M., Koeniger, Chapi, K., \& Malekian, A. (2015). Trend analysis of streamflow in Karkheh Rivers upstream: An evidence for climate change impacts on water resources systems. Journal of Range and Watershed Managment, 68(3), 659-674. (Persian)

Reinsdorf, E., \& Koch, H.-J. (2013). Modeling crown temperature of winter sugar beet and its application in risk assessment for frost killing in Central Europe. Agricultural and Forest Meteorology, 182, 21-30. [DOI:10.1016/j.agrformet.2013.08.001]

Rezaei Banafsheh, M., Jalali Ensroodi, T., Zarghami, M., \& Asghari Moghadam, A. (2015). Investigating the effect of climate change on the groundwater table level of the so-called Tajik basin by statistical microscale scale. Iran Water Resources Research, 11(2), 106-116. (Persian)

Sarafroozeh, F., Jalali, M., Jalali, T., \& Jamali, A. (2012). Evaluation of the effects of future climate change on wheat consumption in Tabriz. Journal of Geographical Space, 12(37), 81-96. (Persian)

Semenov, M. A., Brooks, R. J., Barrow, E. M., \& Richardson, C. W. (1998). Comparison of the WGEN and LARS-WG stochastic weather generators for diverse climates. Climate Research, 10(2), 95107. [DOI:10.3354/cr010095]

Soltani, A., \& Ghoilipur, M. (2006). Simulation of the effect of climate change on growth, yield and water consumption of chickpea. Journal of Agricultural Science and Natural Resources, 13(2), 69-79. (Persian)

Steele-Dunne, S., Lynch, P., McGrath, R., Semmler, T., Wang, S., Hanafin, J., \& Nolan, P. (2008). The impacts of climate change on hydrology in Ireland. Journal of Hydrology, 356(1-2), 28-45. [DOI:10.1016/j.jhydrol.2008.03.025]

Yao, F., Xu, Y., Lin, E., Yokozawa, M., \& Zhang, J. (2007). Assessing the impacts of climate change on rice yields in the main rice areas of China. Climatic Change, 80(3-4), 395-409. [DOI:10.1007/s10584-0069122-6] 